Mavi Atlas, 6(1)/2018: 90-130. Araştırma Makalesi | Research Article

Makale Geliş | Received: 03.02.2018

Makale Kabul | Accepted: 04.03.2018

DOI: $10.18795 /$ gumusmaviatlas.405315

Metin BAL

Doç. Dr. | Assoc. Prof. Dr.

Dokuz Eylül Üniversitesi, Edebiyat Fakültesi, Felsefe Bölümü, İzmir-Turkiye Dokuz Eylül University, Faculty of Literature, Department of Philosophy, İzmir-Turkey

ORCID: 0000-0003-3448-3736

balmetin@gmail.com

\title{
Caydırmaya Karşı Platon'un Lakhes Diyaloğunda ve Aldous Huxley'in Cesur Yeni Dünya Romanında Cesaret Felsefesi
}

$\ddot{O} \mathbf{z}$

Bu yazının amacı “cesaret” konusu hakkında, Platon'un Lakhes diyaloğunun düşünceleri temelinde felsefi bir tartışma yapmayı denemektir. Bu yazı iki yapıt üzerine odaklanmaya çalışır: Platon’un Lakhes’i ve Aldous Huxley'in Cesur Yeni Dünya romanı. Giriş Bölümü'nde "cesaret"in günlük hayatımızda ne anlama geldiği tanıtılır. Birinci Bölüm'de Platon'un Lakhes diyaloğundaki cesaret hakkında felsefi ilk tartışma açıklanmaya çalışılır. İkinci bölümde, çok kısa bir şekilde, Huxley’in Cesur Yeni Dünya romanının felsefi arkaplanının Nietzsche'nin antinihilist düşüncelerine dayandığı söylenir. Üçüncü bölümde Huxley'in Cesur Yeni Dünya romanında "cesaret" incelenir. Sonuç bölümünde her türlü caydırma eylemine karşı birtakım öneriler yapılır.

Anahtar Kelimeler: Cesaret, Caydırma, Lakhes, Platon, Cesur Yeni Dünya, Huxley.

\section{Against Deterrence Philosophy of Courage in Plato's Dialogue Lakhes and in Aldous Huxley's Brave New World}

\begin{abstract}
The aim of this article is to try to make a philosophical discussion about the subject of "courage" on the basis of the ideas of Plato's dialogue Lakhes. This article tries to focus on two works: One is Lakhes by Plato and the other is the novel Brave New World by Aldous Huxley. In the Introduction, the answer of the question "What is courage?" is searched in our daily life. In the first chapter the oldest philosophical discussion on courage in Plato's dialogue Lakhes is tried to be explained. In the second chapter it is argued shortly that the philosophical background of Huxley's novel Brave New World is based upon Nietzsche's antinihilist ideas. In the third chapter the idea of courage in Huxley's Brave New World is investigated. In the conclusion some suggestions against any act of deterrence are given.
\end{abstract}

Keywords: Courage, Deterrence, Lakhes, Plato, Brave New World, Huxley. 


\section{Giriş}

Lakhes diyaloğunda Sokrates Lysimakhos'a şöyle demişti: "Beni çağırdığın sürece gelmeye [...] ve hepinizi ikna etmeye çalışırım."1 O halde, konumuzla ilgili olarak çağıralım Sokrates'i ve felsefe yapalım. Ancak, Sokrates'i çağırmadan önce, filozofun ne olduğu ve filozofla nasıl başetmemiz gerektiğiyle ilgili Nikias'ın söylediği bilmemiz gereken birkaç şey var: Çok sabırlı olmalıyız, çünkü filozof "bir kere konu açıldıktan sonra [...] onu sonuna kadar zorlamaya devam eder." (L, 188a, 47) İkinci olarak, filozof konuşurken sakın orda yokmuş numarası yapmayalım, çünkü filozof sözleri öyle birbirine bağlar ki "lafın [...] dönüp dolaşıp bize geleceği” kesindir. (L, 188b, 47) $\mathrm{Bu}$ nedenlerle filozofla "konuşmaya başladığımızda bu duruma katlanmak [...] ve ondan hiçbir şekilde kurtulamayacağımızı" bilmemiz gerekir. (L, 188a, 47)

Olaylar büyür. Onlar bizim olayımızsa daha fazla büyürler. Olaylar "cesaret” gibi doğrudan bizim tutkularımızı ilgilendiriyorsa büyümeleri kaçınılmazdır. Dikkatli bir şekilde bakacak olursak her sanat yapıtının, her kitabın cesaret çağrılarıyla dolu olduğunu görürüz. Edebiyat dünyasının başyapıtlarının hemen hemen tamamında olaylar cesaret gösteren kimseler ve korkaklık gösteren kimseler etrafında döner. Tiyatro sanatının başlatıcısı Aiskhylos, bana göre başyapıtı Zincire Vurulmuş Prometheus tragedyasını Prometheus'un cesareti üzerine kurmuştur. Theseus'u Prokrustes'in işkencelerini cesurca sonlandırmasından biliyoruz. Perseus'u Medusa'yı yendiği cesaretinden tanıyoruz. Illyada destanında anlatılan Troya savaşı Paris'in korkak tavrıyla başlamış, ancak Akhilleus'un cesareti üzerine kurulmuştur. Akhilleus'un betimlediği gibi göğsünde “demirden bir yürek” taşıyan Troya kralı Priamos'u, oğlu Hektor'un cesedini almak üzere Akhilleus'un çadırına korkusuzca girerken sergilediği cesaretinden tanıyoruz. (Homeros 2005: 526, 24. Bölüm) Odysseus'u sirenlerin cazibesine kapılmamak için gösterdiği kararlı cesaretinden biliyoruz. Cervantes'in Don Quixot'unu cesaretiyle tanıyoruz. Shakespeare'in Macbeth tragedyasında ise merakına yenilerek korka korka kral olmuş ama tahta oturamamış Macbeth’i korkaklığıyla

\footnotetext{
1 s. 38, 181c, d. Platon (2011). Lakhes, çev. Furkan Akderin, İstanbul: Say Yayınları, ss. 35-65. Yazı içinde bu kitaba "L" kısaltmasıyla gönderme yapılacak ve ardından önce paragraf numarası, sonra sayfa numarası verilecektir.
} 
biliyoruz. Bertolt Brecht'in Cesaret Ana ve Çocuklarl oyunundaki anayı savaş çağrılarına karşı çocuklarını koruma çabasıyla sergilediği cesaretiyle tanıyoruz. Bunların hepsinin ötesinde, Sokrates’i düşünme çabası ve düşüncesini açıklama konusunda gösterdiği cesaretiyle biliyoruz.

Cesaret her zaman korku ile bir arada düşünülür. Cesaret konusunu daha iyi anlamak için, öncelikle, "korku”nun psikolojik ve metafizik türünü birbirinden ayırmalıyız. Korku psikologlar tarafından "ilkel bir duygu” olarak tanımlanır. Korkunun bu psikolojik türleri ${ }^{2}$ doktor ve hasta arasındaki görüşmelerle düzeltilebilir. Ancak bir insan klostrofobiyi yenip asansöre bindiği için ya da niktofobiye direnip gece evinin salonunda oturabildiği ya da hidrofobiyi aşıp derin sularda yüzüyor olduğu için ona cesur demiyoruz. Buna rağmen, bir kimse psikolojik olarak hangi konuda zorluk yaşıyorsa, o konu onun için korku vericidir. Böyle durumdaki bir kimsenin göstereceği cesaret kendisiyle sınırlıdır. Elbette her şeyi yapabilecek gücü olduğunu düşünen bir kimse daha fazla korkmaz. Hiçbir şeyden korkmayan böyle bir insana hasta gözüyle bakılır. Psikolojik korkunun nedeni geçmişte yaşanmış deneyimlerdir, ancak cesaret sadece geçmişle ilgili olarak kaçınılması ve göze alınması gerekenlerin farkında olmak değildir. $\mathrm{Bu}$, cesaretin üçte birinin tanımıdır. Haberimiz yok ama belki de şimdi ya da gelecekte korkulacak birşeyler vardır. Korkunun psikolojik türü bakımından psikologlar psişik varolan türlerini birbirleriyle karşılaştırabilirler. İnsanlarda olduğu gibi diğer türlerde de korkunun psikolojik türlerinin var olduğunu ve bunun nedenlerini kısmen biliyoruz.

Korkunun yukarıda değinilen psikolojik yönünü anlamak zor değildir. Hatta tedavisi de mümkündür. Ancak korkunun asıl dehşet verici yönü onun metafizik boyutudur. Korkunun ve varoluşumuzu aşındıran bu temel duygu durumunun alt edilmesi demek olan "cesaret”in metafizik bir yönü vardır, çünkü insanın kendi aklını

\footnotetext{
2 Psikolojik korku türlerinin en yaygın olanları: Agorafobi (kalabalıklar ortasında yalnız başına kalma korkusu), klostrofobi, zenofobi (yabancı ve farklı olandan duyulan korku), akrofobi (yükseklik korkusu), basifobi (düşme korkusu, yürürken olduğu gibi yatarken de hissedilebilir), araknofobi (örümcek korkusu), koulrofobi (palyaço korkusu ya da maskeli kimselerden korku), niktofobi (karanlıktan duyulan korku), emetofobi (kusma korkusu), hematofobi (kan korkusu), hidrofobi (su korkusu), zoofobi (hayvanlardan duyulan korku), agirofobi (karşıdan karşıya geçme korkusu), monofobi (yalnız kalma korkusu), vb.
} 
kullanması bir cesaret sorunudur. "Aklını kendin kullanmak cesaretini göster!” sözü Kant'a göre Aydınlanma felsefesinin parolasıydı. (Kant 1984: 213) Aklı kullanmak cesaret gerektirebilir ancak buna rağmen Sokrates'in göstereceği gibi akıl sahibi olmak ve cesur olmak arasında bir ilişki yoktur. Başka türlü ifade edecek olursak, bilgili olmak cesaret göstermek için gereklidir ancak yeterli değildir. Korkunun metafizik boyutuna birkaç örnek vermek istiyorum. İnsanların çoğundan daha fazlası güvenli bir evrende yaşadıklarını düşünürler. Oysa her an bir meteor dünyaya çarpıp onu yok edebilir. Yine bu insanların çoğunluğu, öte dünya anlayışı demek olan eskatolojik inançlara sahip olmakla, sona erdikten ya da öldükten sonra yaşamlarının bir şekilde güvenli olarak devam edeceğinden emin yaşıyorlar. Özellikle bu iki örnek, korkunun metafizik boyutuyla ilgili en sık karşılaştığımız durumlardır. Korkunun metafizik boyutunun en masum ve herkeste karşılaşabileceğimiz şeklini, bir kimsenin belirli bir yaşam tarzına sadık kalmasında, hatta yaşama dair sürdürdüğü bu şeyi "yaşam tarzı” diye bir şeyin farkında bile olamayacak şekilde kanıksamış olmasında, ve bunun dışına çıkma düşüncesinin onun için "korku" verici olması durumunda buluyoruz. Elbette yaşamımızın tarzını ve koşullarını biçimlendirmek, dünyayı istediğimiz tarzda değiştirmek büyük bir cesaret ve yoğun bir çaba gerektirir. Bunu yapanlara "cesur insanlar" ya da daha teknik olarak "kahramanlar" ya da "devrimci" insanlar diyoruz.

Gösterildiği yerlerde cesaretin miktarı her zaman fazladır. Cesaret her göründüğü yerde kendisini beklenilenden fazlasıyla ortaya koyar. En azından birbirini cesaretlendirmek isteyen kimseler birbirlerine beklenilenden fazlasını vermelidirler. Bunu yapabilen insanların bir kısmına filozof diyoruz. Bir adım daha ileri giderek, cesaretin bir ölçüsü olup olmadığını sorabiliriz. Cesaretin Lakhes'in söylediği ve Sokrates'in onayladığı gibi, doğru görünen bir ölçüsü söz ve eylem arasındaki uyum olarak kabul edilir, çünkü cesur olduğu söylenen kimselerin söz ve eylemleri arasında bir uyum olmasını bekleriz. Böyle olmadığında bu durumun bir şarlatanlık olduğunu düşünürüz. Lakhes, fillozofun tanımını bu ölçüte göre yapar. Buna göre filozof "yaşamı ve sözleri birbirine uydurup en güzel ahengi yaratan kimsedir.” (L, 188d, 48) Sokrates tartışmanın geldiği noktada "söylediklerimiz ve yaptıklarımız arasında uygunluk 
bulunmuyor." (L, 193e, 55) olduğunu farkettiğinde, "işte burada metanet/dayanıklılık göstermek cesarettir.” (Plato 1952: 194a, 57) diyerek, filozofa yakışan bir şekilde cesurca davranılması gerektiğini önerir. Şöyle der: “Cesur davranalım ve araştırmamızı devam ettirelim." (194a, 55) Bunun devamında "düşünce" "söz kalıbına dökülerek kuvvetlendir"ilmeye devam edilmelidir. (L, 194c, 56)

Cesaret göstermek bir refleks değildir, arkasında bir düşünceyi barındıran kararlı bir tutumdur. Gösterilmesi gerektiğini düşündüğümüz yerde, cesaret, kendisini aynı anda ortaya koymayabilir. Böyle zamanlarda cesur olmamak korkak olmak anlamına gelmez. Cesur olabilmek için önce cesurca düşünmek gerekir. Cesaretin gösterilmesi gereken uygun bir zamanı vardır. Bunun için en azından bu konuda yargılanacak kimsenin yaşamının bilinmesi lazım. Herkesin cesaret zamanı farklı olabilir. Bu nedenle cesaretin zamanı yoktur. Cesaret ansızın meydana gelir, çünkü o tüm zamanları bağlayan bir bağdır ve tüm zamanlar bir kimsenindir. Cesaret tüm zamanların bilgisini dikkate alır. Hiç beklenmedik birinden ansızın bir itirazla karşılaşabiliriz. Böyle zamanlarda cesaret kendisini sert bir şekilde ortaya koyar, çünkü bunu yapan kimse bu eyleminin her zaman geç bile kaldığı hissine sahiptir. Cesaret için uygun zaman ve koşullar bir hazırlık süreci gerektirir. Cesaret "korku yokluğu" anlamına gelmez. Cesaret göstermek, öncelikle, "korkutucu olan"ın ve bu şekilde etkileyenin farkında olmak, neyden kaçınılması ve neyin göze alınmasını bilmek ve korku verici olan bu şeyle mücadele etmenin yollarını düşünmektir. Cesaret bu kararın eyleme geçirilmesiyle sergilenmiş olur. Eyleme geçirilmemiş bir bilgi olarak kalmış cesaret, eylem gücünün aşındırılması, acizlik, düş kırıklığg, pişmanlık, hüsran ve umutsuzluk yaratır. Cesarete ilişkin bu zavallı durumlar, bir şey yapmış olmaktan değil, bir şey yapmamış olmaktan kaynaklanır. Cesaret gösterisini sahneye koymak için onun hikayesini ortaya koymamız, başka bir deyişle, tarihselleştirmemiz gerekir. Cesaret bu anlamda zamanları birleştiren bir erdemdir. Bir kimsenin cesur olup olmadığını elbette onun kendi hikayesi içinden anlayabiliriz.

Cesaretten söz etmek çok risklidir, çünkü kimse korkak olduğunu kabul etmek istemez ve herkes şimdiden cesur olduğunu ve gerektiğinde böyle olduğunu 
gösterebileceğini de düşünür. Böyle bir düşünceyle fantastikleştirdiğimiz kendi dünyamızda kurtarıcı, yıkıcı ve kurucu kahramanlar olarak dolaşırız. Neden “cesur ol!” deriz, neden kendimizden ve başkalarından "cesaret" bekliyoruz? Çünkü kesintisiz inletici acıları, bitimsiz 1stırabı, sonu gelmeyen dehşeti bir an önce sonlandırmak istiyoruz. Bunu gerçekte yapamıyorsak da önce mümkünse düşüncede yapmaya çalışıyoruz, düşüncede yapamıyorsak da bu acıları çekenleri uyuşturmaya, uyutmaya çalışıyoruz. İnsan doğasının en tuhaf bulduğum özelliği onun ister istemez düş gören, hayal kuran bir varolan olmasıdır. Eğer istediğimiz bir yaşam tarzı ile mevcut düzen arasında kapatmaya gücümüzün yetmeyeceğini düşündüğümüz bir uçurum var ise, bu uçurumu yaratıcı eylemlerle kapatmaya çalışmaktansa yaşamın akışı içinde kendimizi alışkanlıklarla, şartlandırmalarla uyuşturmayı tercih ediyoruz, çünkü düşler, morfin ${ }^{3}$, opioid $^{4}$ ya da uyuşturucular yoluyla var olmayan şeyleri varmış ya da var olan şeyleri yokmuş gibi deneyimleyebiliriz. Rasyonel tüm zihinsel güçleri bir tarafa bırakan mucizelerden biridir bu. Böylece Cesur Yeni Dünya ${ }^{5}$ (CYD) romanında Fordgil Bilim Gözlemcisi'nin dediği gibi “kötülük gerçek olmaktan çıkar” (CYD, 247) ve Diğer Taraf'ın 10 denetçisinden biri olan Batı Avrupa Bölgesi Denetçisi Mustafa Mond'un dediği gibi “gerçeklerden uzaklaşabilirsiniz.” (CYD, 236) Bugün insanların kendilerini, tamamı toplumsal olarak ve toplumun neredeyse tamamının işbirliğiyle üretilen doğal ve sentetik maddeler yoluyla uyuşturmalarının olanakları sınırsız denilecek kadar çoktur: Doğal uyuşturucular olarak haşhaş, afyon, adam otu olarak bilinen mandragora ve marijuana gibi esrar türleri, eroin, metamfetamin, kokain, kubar, mantar, afgan. Bunların yanında, sentetik psikoaktif maddeler olarak LSD ya da asit, DNT, ekstasi gibi hap türleri, bali, bonzai, krokodil olarak bilinen desomorfin, flakka, banyo tuzu ya da

${ }^{3}$ Grek mitolojisinin düşlerle ilgili tanrı, tanrıça ve yarı tanrılarına Oneiroi denir. Grekçe "oneiroi" (Latince "somnia”) Phantasos (Grekçe görünme, imgesel cisimleşme demektir.) ve Hipnoz (Uyku) ve düşleri cisimleştirip gösteren Morfeus bunlardan üçüdür.

${ }_{5}^{4}$ Opioid: Narkotik ya da uyuşturucu etki gösteren kimyasal maddeler.

${ }^{5}$ Huxley, Aldous (2017). Cesur Yeni Dünya, çev. Ümit Tosun, sunuş: Margaret Atwood, sonsöz: David Bradshaw. İstanbul: İthaki Yayınları. Bu yazı içinde yapılan referanslarda Cesur Yeni Dünya romanı CYD kısaltmasıyla gösterilecektir. 
sentetik katinon, skopolamin ${ }^{6}$, fentanil ${ }^{7}$ vb. Bu saydıklarımın yanında, hepimizin en çok kullandığı bağımlılık yaratan maddeler televizyon, radyo, internet, dini ibadet ve fuhuş kurumları, kumar, spor ve şans oyunları, yarışmalar, turistik geziler, kitlesel doğa yürüyüşleri, aynı dertten müzdarip olduklarını düşünen insanların bir araya geldikleri çeşitli dayanışma grupları, falcılık, şeytan kovma, ruh çağırma, pozitif enerji toplama gibi irrasyonel faaliyetler ve başka hiçkimsede olmama, yalnızca sizde olma gibi hasta bir ontolojiye dayanan koleksiyonculuk ya da biriktiriciliğin aklınıza gelen her türü, örneğin para biriktiriciliği, mücevher biriktiriciliği, pantolon, araba, çiçek, film, müzik parçası hatta kitap ve sonunda arkadaş biriktiriciliği. İşte bunlarla, arzularımız ve sistem arasında kapatılması imkansız olduğuna inandığımız bu uçuruma kendimizi bırakmaktan zevk alırız. Bireyler şartlandırılmış günlük hayat düzeninde bu saydığım uyuşturucu ve bağımlılık yaratan maddeler içinde konforlu bir şekilde yaşarlar. Bireyleri uyuşturma yoluyla düzen altına alan uygulamaları teknik olmayan ikna ya da inandırma yollarına dahil edebiliriz. İnsanlar birbirini ikna etme çabasında düşünmekten, diyalogtan ya da Nikias'ın hatırlattığı "doğru düşünmeyi kullanmaktan” (Platon 2011: 56, 194c) vazgeçtikleri anda, Aristoteles'in dediği gibi, uyuşturucu maddeler, "yasalar, tanıklıklar, anlaşmalar, işkenceler ve yeminler" ${ }^{8}$ gibi teknik olmayan inandırma yollarına başvururlar. Diyaloğun bittiği yerde insanın insana şiddeti başliyor. Sistem, bireyleri uyuşturarak kitleselleştirir ve bu kitlenin yetiştirilmesinde bireyin değil her zaman toplumun ya da ülkenin yararını gözetir. Sistemin koşullarıyla “öylesine şartlandırılırsınız ki, sizden beklenenleri yapmamak elinizde değildir.” (CYD, 235) Bu nedenle Cesur Yeni Dünya romanında yalnızlık ve bireysellik hastalık ya da “antisosyallik" (CYD, 132) olarak görülür. Yalnızlık ya da tek başınalığın sıkıcı olduğu önyargısı sayısız şartlandırmalar sonucunda zihnimize yerleştirilmiştir. Çoğunluk benzer şeyler yaptığı için kendimizi gayet rahat ve konforlu bir durumda hissederiz. Hayatın yalnızca belirli bir biçimde akması gerektiğini ve bu akışın yalnızca bir biçimde

\footnotetext{
${ }^{6}$ Skopolamin: Ticari adı "hyosein"dir. Halk ağzında "gerçeklik serumu", "cadı tozu" ya da "şeytanın nefesi" olarak bilinir. Yüksek dozda alındığında hipnotik etki ve halüsinasyon yaratıp derin uykuya neden olur.

${ }^{7}$ Fentanil: Yaygın adı "sublimaze" olan narkotik ya da opioiddir.

${ }^{8}$ Aristoteles 2008: 1355b 39-40, s. 37 ve 1375a24, s. 87.
} 
düzeltilebileceğini düşünüyorsanız, hayatın akışına yardımcı olmak için başka bir şeye bağlanmışsınız demektir. Bu bağımlı olduğunuz şey yaşamsal olarak zindelik ve mutluluk hissi verir. Bağımlı olduğunuz şeyden aşırı miktarda yararlandığınızda bu durum kendinizin ya da başkasının hayatını ölümle sonuçlandırma riski taşır. O zaman herşeyinizi dengede tutmalısınız, çünkü sistem dengede durur.

Cesur olmak umutlu ya da umutsuz olmak anlamına gelmez. Umut, beklenilen bir şeydir ve ne beklediğinizi bilirsiniz. Üstelik, gerçekleşme anında yok olur umut. Umut, yerine gelmesi gerektiğini düşündüğünüz şeyi çağırmak için vardır. Cesaret göstermek gelecek olanı getiriyor olduğu için umuda gerek yoktur. Birini çok seviyorsunuz, ona sarılmanıza rağmen hala özlüyorsunuz, çünkü umutlusunuz. Aşk cesarete zorluyor. Ancak sevgili de sizi sevdiğinde durum değişir. Özlem sonlanır, çünkü umut gerçekleşmiş, başka bir deyişle yok olmuştur. Cesaret gösterildiği anda umut gözden yiter, çünkü ordasınızdır artık. İstediğiniz yere geçmek üzeresinizdir. Bu nedenle Cesur Yeni Dünya umudun daha fazla olmadığı, cesaret gösterilmesi ve sistemin kökten bir şekilde yıkımının kaçınılmaz olduğu bir çağı anlatır. Mevcut düzeni iç rahatlığıyla sürdürüyoruz, çünkü çoğunluğun yanılgısı hata olarak değerlendirilmez. $\mathrm{Bu}$ hata "hayatın" kendisine yüklenir. Özellikle yaşlılar "İşte hayat böyle" derler. Ancak aslında hayat hiç de öyle değildir. Hayat öyle olmak zorunda değildir. Sokrates'in Lakhes diyaloğunda dediği gibi her zaman "başka bir yol daha var"dır. (Platon 2011: 49, 189d)

\section{Bölüm: Platon'un Lakhes Diyaloğunda Cesaret}

İlki "Bir kimse nasıl yetiştirilmelidir?" sorusu ve ikincisi, bu sorunun doğru cevabının altında yattığını düşündüğüm “ “cesaret” konusunun düşünmeyle ve düşünce gücüyle ilişkisi” Platon'un (427-347) Lakhes diyaloğu ve Aldous Huxley'in (18941963) Cesur Yeni Dünya romanını birleştirebileceğini düşündügüm iki ortak meseledir.

Lakhes diyaloğunda, Atina kentinin önde gelen saygın dört yaşlı adamı Lysimakhos, Melesias, Nikias ve Lakhes -kendi çocuklarını- Lysimakhos'un oğlu Aristides, Nikias'ın oğlu Nikeratos ve Melesias'ın oğlu Thykidides. Lakhes'in de bir 
oğlunun olduğu söylenmesine (L, 187d, 46) rağmen adı anılmaz-, boş zamanlarında zararlı şeyler yapmalarındansa, şimdiden bir erdem olduğunu düşündükleri cesaret konusunda eğitilmek üzere, savaş aletleri kullanmayı öğrenebilecekleri bir yere götürmüşlerdir. Diyalog bu alanda başlar. Bu yaşlı ebeveynler böylece "çocuklara mümkün olduğunca sahip çıkmaya" (L, 179a, 35) çalıştıklarını düşünürler. Çocukları "kendi haline bırakmak" istemezler, çünkü onların "iyi yetişmesi”ni (L, 179a, 35,), “ülkelerine yararlı” (179c) olmalarını, "şan şeref kazanma”larını (L, 179d, 36) ve “erdemli birer insan" (179b) olmalarını arzularlar. Nikias da gençlerin boş zamanlarında “özgür bir insan”a (L, 182a, 39) yakıştığını düşündüğü “yararlı” ve “çaba” (L, 182a, 39) gerektiren şeyleri yapmalarını doğru bulur.

Burada olduğu gibi, ebeveynlerin çoğunluğu kendi çocuklarını yetiştirirken, onların almaları gerektiğini düşündükleri eğitimin ne olacağına, kendilerinde eksikliğini duydukları ve olması gerektiğini düşündükleri şeylere ya da kendilerinin gerçekleştiremedikleri kendi hayallerine bakarak karar verirler. Bunun ne kadar yanlış bir tutum olduğunu böyle bir eğitime maruz bırakılmış çocuklara sormak lazım. Bu tutum yanlıştır çünkü çocukların bireysel varoluşlarını göz önünde tutmamaktadır. Yakından bakacak olursak, bu diyalogtaki ebeveynlerin çocukların eğitiminde merkezi bir önem verdikleri “ülke”, "erdem”, "iyilik" gibi kavramların çocukların hayatıyla hiçbir ilgisi yoktur. $\mathrm{Bu}$ yaşlı ebeveynlerin kendilerine dayanarak çocuklarına öğretebilecekleri hiçbir şeyleri olmayınca da, eğitim söz konusu olduğunda, onların bu alandaki yaygın kanıları ve uygulamaları benimsemeleri kaçınılmazdır. Çoğunluk, çocukların yetiştirilmesi gibi en önemli konularda bile hiç tartışmamış olmayı tercih eder. Eleştiri kültürünün gelişmemiş olmasının en büyük nedeni budur. Lysimakhos, Sokrates'e söylediği “Baban ölene kadar kendisiyle en ufacık bir tartışmamız bile olmadı." sözüyle bir kimseyle hiç tartışmamış olmayı bir dostluk belirtisi olarak değerlendiriyor. (L, 180e, 37) Bunun nedeni, sıradan insanlar arasındaki tartışmanın çoğunlukla şiddetle ve nefretle sonuçlanmasıdır.

Sistemi olduğu haliyle en çok destekleyen ve sürdüren kuşak yaşlılardır. Onlar böyle oldukları için suçlanamaz, çünkü onların böyle olmasının tek nedeni kendileri 
değildir. İnsanların yaşları ilerledikçe dünyadan daha çok koptuklarını görüyorum. Çoğu zaman insanların daha fazla eğitim almamış olduklarından dolayı pişman olduklarını düşünürüz. Bunun büyük bir yanılgı olduğunu, iş hayatına girmeleriyle birlikte eğitim hayatlarının bittiğini düşünen kitlelere baktığımızda anlayabiliriz. İşyerindeki çalışanların, almış olduklarından daha fazla bir eğitim önerisini birbirlerinden beklediklerini mi düşünüyorsunuz? Hepimiz şunu biliyoruz ki iş hayatıyla birlikte tüm defter ve kitaplar kapatılmış, diploma dosyalanmış ve dosya patrona sunulmuştur. Lakhes diyaloğundaki bu saygın yaşlı kimselerin durumu da böyledir. Onlar dünyadan öyle kopmuşlardır ki yıllardır çok yakınlarında oturup kalkan Sokrates'in ne iş yaptığını bile bilmezler. Lysimakhos bunun nedenini şöyle itiraf ediyor: "Bizim yaşımızdakiler gençleri fazla tanımıyor, yaşlılık, zamanımızın çoğunu evimizde geçirmemize neden oluyor.” (L, 180d, 37) Çocuklara eğitim verilmesi gerekiyorsa ve bu eğitim konusu cesaret ise, henüz bu konuda bir öğretmen tanınmamasına rağmen, cesaret konusunda hiç olmazsa cesur olarak tanınmış bir kimseye danışılabilir. Bu kimse Sokrates olabilir çünkü o, Lakhes'in “Delion Savaş1 yenilgi” sinde tanık olduğu gibi aynı zamanda cesur biridir. (L, 181b, 38)

Erdem konusunda bir şey öğretilebilir mi öğretilemez mi bu tartışmayı bırakalım sürüp gitsin. Önemli olan bir şey var burada, o da şu ki "bilgi” bir konudaki hakikatin ne olduğu araştırmasında bizi çoğunluğun yanılgısından kurtarır. Sokrates'e göre doğruluk hakkındaki ölçüt "çoğunluğun” kararı değildir. (L, 184d, 42) Sokrates'in dediği gibi bir konudaki "doğruluk" araştırmasında çoğunluğun ya da "sayının değil bilginin önemi vardır." (L, 184e, 42). Sokrates diyor ki "Konudan anlayan birisi var mı [...] öncelikle buna bakalım. [...] o diğerlerinden farklı bile konuşsa, onu dinlemeliyiz." (L, 185a,42)

Sokrates çocukların yetiştirilmesi ve eğitimi konusunda ebeveynlerin hiçbir çabadan sakınmamaları gerektiğini önerir. Çocukları yetiştirmek konusunda "en büyük zenginliğinizi ortaya koymuyor musunuz?" diye sorar. (L, 185a, 43) Lysimakhos ve Melesias'ın bu bakımdan elle tutulur bir tarafları vardır çünkü böyle olmalarına rağmen en azından çocukları için bir şeyler öğretebilecek kimseleri aramaya koyulurlar. Hiç 
olmazsa onlardaki iki özellik, ilki öğretecek bir şeyleri olmamasından duydukları "utanç" (L, 179c, 36) ve diğeri, iyi bir eğitim bulma arayışı felsefi bir tutumdur.

Yaşlıların şu anda içinde bulundukları kötü durumdan ebeveynlerini sorumlu tutmaları ve onlar tarafından "kötü yetiştirilmiş" olmalarından şikayet etmeleri, kulağa tuhaf hatta komik gelir. Ya da öğretmeninize bir soru soruyorsunuz ve o size, kendisine kötü bir eğitim verilmiş olduğu için bu sorunuzu cevaplayamayacağını söylüyor. Bu daha komik bir durumdur. Şikayet konusunda malzeme bulmak kadar kolay bir şey yoktur. Korku sağlam bir bahaneyle gelir. Ancak, kimin şikayete ihtiyacı var ki? Yukarıda sözü edilen bu yaşlıları ve böyle bir öğretmeni kolayca anlayabiliriz, ancak bir de otodidakt ${ }^{9}$ ların yaptı̆̆ 1 "kendi kendini yetiştirmek" diye bir şey vardır. Sokrates diyor ki "Bazı sanatlarda kimi insanlar, hiçbir ustaları olmamasına rağmen, ustası olanlardan daha ileri gitmişlerdir”. (L, 185e, 44) Sokrates'in kendisi de bir otodidakttır. Şöyle diyor Sokrates: “[...] Size kendimden bahsedeyim. Bana kimse bu konularda bir şey öğretmedi ama bu işlere gençliğimden bu yana ilgi duydum. Beni yetiştirebileceklerini söyleyen Sofistlere ödeyecek param yoktu.” (L, 186c, 45) Nikias’a göre insanlar yaşları ilerledikçe akılları da kendiliğinden artıyor değildir. Bu nedenle Nikias Solon'un “Yaşadıkça öğren!” (L, 188b, 47) sözüne uygun davranmak gerektiğini düşünür. Ancak Lakhes gerçekten öğrenmek için mutlaka "öğreten değerli bir insan" olması ve bu öğreten kimsenin "iyi bir insan olması" (L, 189b, 48) gerektiğini savunur. Sokrates bu düşünceye katılır ancak onun için öğrenme konusunda başka bir yol daha vardır: Kendi kendine öğrenme anlamına gelen otodidakt.

Sokrates, iyi öğrenmiş ve öğretme konusunda iyi olduğunu söyleyen bir kimsenin ya iyi bir öğretmen adı vermesini ister ya da bu kimsenin, eğer o kendi kendini yetiştirmiş otodidakt biriyse, onun kendisinin bu konuda iyi olduğunu gösteren hangi öğrencileri yetiştirmiş olduğunu göstermesi gerektiğini düşünür. Bir kimsenin bir sanat konusunda usta olduğunu söylemesinin bir inandırıcılığı yoktur. Sokrates'e göre bu konuda inandırıcı olmak isteyen bir kimse kendi yaptığı "birkaç güzel eser"i

\footnotetext{
${ }^{9}$ Grekçe "Autodidaktos" "kendi kendine öğreten" anlamına gelir. Grekçe "autos": kendi. "Didaskein": ögretmek.
} 
göstermelidir. (L, 186a, 44) İyi bir hoca olduğunu iddia eden biri, kendi yetiştirdiği iyi öğrencileri göstermelidir. Örneğin, Platon gibi bir öğrenci, Sokrates’in öğrettiklerini yazılarıyla açıkladığında, o zaman Sokrates kendi yapıtını göstermiş ve iyi bir öğretmen olduğunu kanıtlamış olacaktı. İyi bir eğitimin ne ve nasıl olması gerektiği hakkında düşünen bir kimse ne bir öğretmen adı veriyor nede kendi yapıtını gösterebiliyorsa o zaman, iddia edilen durum eğitim hakkında bir ilk deneme olacaktır. Üstelik konu cesaret olduğunda bir öğretmen bulmak Lakhes diyaloğunda gösterildiği gibi neredeyse imkansızdır. Cesaretin eğitimle ilişkili en tuhaf özelliği, onun, şimdiye kadar size öğretilenlerin işe yaramadığı, boşa çıktığı, ne yapmanız ve düşünmeniz gerektiğini bilmediğiniz durumda kendisini sizde zorlayan bir şey olmasıdır. Cesaret, artık dinleyecek bir otoritenin kalmadığını, otoritenin daha fazla otorite kanıtı sergileyemediği ve sizin gözünüzde otoritenin kendi meşruluğunu yitirdiği zamanlarda takındığınız bir tavırdır. Cesaret yazılı kurallarla düzenlenemeyen ve düzenlenemez, dahası bir yasaya bağlanamaz, hatta zaman zaman yasanın kendisine aykırı davranmanızı gerektiren bir erdemdir. Öğrendikleriniz şimdi boşa çıktı ve kendisinden öğrenecek bir kimse de bulamadınız. Nihayet, artık kendinize öğretecek olan sizsiniz. Üstelik cesaret gibi, hiçbir şey bilmediğiniz bir konuda bir başlangıç yapabilmek, Sokrates'in dediği gibi "tehlikeli bir iştir." (L, 187a, 46) Sokrates bu durumu bir atasözüyle açıklıyor: "Şarap küpü yaparak çömlekçiliğe başlanmaz.” (L, 187b, 46) Buna göre, demek ki insanların çoğu, konu ne olursa olsun eğitime şarap küpü yapmak gibi zor bir yerden başlıyor. Diyaloğun sonunda cesaret hakkında hiç kimsenin tam bir tanım yapamamış olduğunu gören Sokrates, bu nedenle Lysimakhos'a, ona öğretecek bir öğretmen tavsiyesinde bulunamayacak ve şöyle diyecektir: "Bence hiçbirimizi seçme. [...] Bence bu çocuklardan önce kendimize bir öğretmen bulmalıyız, [...] Eğer bu yaşta okula gittiğimizi görüp bizimle alay eden birileri olursa, kendimizi onlara Homeros'un "Yoksulluk ve utanma bir arada olmaz"10 şeklindeki sözlerini hatırlatarak kurtarırız." (L, 200e, 201 a, b, 65)

\footnotetext{
${ }^{10}$ Plato 1952: 81 / Telemakhos: "çekinmek yakışmaz yoksulluk içinde olan adama." (Homeros 2005a: “On Yedinci Bölüm”, s. 297)
} 
Lakhes diyaloğunda, cesaret hakkındaki felsefi ilk tanımı Nikias yapar. Ona göre cesaret bilgidir ve bir kimse cesareti öğrenmeye silah ya da savaş aletleri eğitimiyle başlayabilir. Nikias'ın bu görüşlerine karşı olan Lakhes'e göre cesaret hakkındaki bilgi cesur olmayı sağlamaz, çünkü "cesur olmayan bir insan da kendisinde bu bilginin olduğunu iddia" edebilir ve böylece "komik duruma düşer." (L, 184c, 41) Silah kullanmayı tüm askerler bilmesine rağmen her asker cesur değildir. Savaşan herkes savaşmayı bilir ancak sonuçta bir taraf kazanır. Bir adım geriye giderek şöyle diyebiliriz: İyi bir savaşçı, iyi bir tragedya yazarı gibi o konudaki bilgiyi öğretmekten çok onu uygulayan kimsedir. Bu nedenle bir kimsenin silah kullanmayı iyi bilmesi onun silah kullanmayı iyi öğretebileceği anlamına gelmez. Lakhes: “İyi tragedya yazabilen bir insan, kalkıp Attika'nın etrafında kent kent dolaşmaz, bunun yerine oyunlarını bizim karşımızda oynatır ve çok da doğru yapar.” (L, 183b, 40)

"Cesaret için bilginin bir önemi yok” demek istemiyorum, yalnızca Lakhes’in dediği gibi "cesaret göstermek" ile "cesaret hakkındaki bilgi”nin iki ayrı şey olduğunu söylüyorum. Cesaret hakkında bir konuşma açıldığında herkesin aklına önce cesaretin nasıl öğrenilebileceği ve nasıl cesur olunabileceğiyle ilgili örnekler gelir, ancak “cesaret”in kendisinin "ne olduğu” (L, 185b, 43) sorusu çoğu zaman hiç sorulmadan kalır. Bu durum merhem çeşitlerinden bahsederken, merhemin kendisi için üretildiği gözü unutmaya benzer. Böylece günlük konuşmalarımızda konunun aslı hep ertelenir. Bir türlü asıl konuya varılmaz. Ancak "İki şeyden birini diğerinden dolayı düşünüyorsak, asıl konu o değildir.” diyen Sokrates asıl konuya gelmek ister. (L, 185e, 44) Asıl konu“cesaret nedir?" sorusudur ve cevaplarken ilk akla gelen şey, onun bir “erdem” olduğudur. Cesaret eski Grekçe'de “andreia”, Latince'de aynı zamanda "ruh gücü” ya da "ruh sağlamlığı" anlamına gelen "fortitudo" sözcüğüyle ifade edilir. Sokrates'e göre öncelikle "erdemin ${ }^{11}$ ne olduğunu bilmek" gerekir. ${ }^{12}$ Erdemin ne

\footnotetext{
${ }^{11}$ Gr. arete, İng. Virtue. Plato 1952: 44.

12 Konunun Platon'un Devlet metninde geçtiği şekliyle, "felsefe"nin de kişiliğinde cisimleştiği "birey”in "pathos"u (içinde bulunduğu duygu durumu) çerçevesinde anlam kazandığına dikkat edilmelidir. Öyle ki Platon'da "cesaret (andreia)" tartışması, ana bir "pathos"a veya "güç"e (dunamis), yani "thumos"a bağlı olarak gelişmiş; fakat daha öncesinde, Platon bakımından "cesaret"i diğer erdemlerle uyum içinde
} 
olduğunu bilmiyorsak, "onu elde etmenin en iyi yolunu” (L, 190c, 50) söyleyemeyiz. Cesaretin ne olduğunu bulmak için onun nasıl bir erdem olduğuna bakılması gerekir. Herkes silahla dövüş sanatının “cesaretle ilgili olduğunu düşünür.” (L, 190d, 50) Cesaretin bir erdem olarak ne olduğu bilinmemesine rağmen, silahla dövüşmenin cesaretle ilgili olduğu düşünülmektedir.

Sokrates burada tartışılan konunun "gençlerin ruhunun eğitimi"13 ya da "gençlerin ruhu uğruna"14 "manevi eğitim” olduğunu saptıyor. Böylece Lysimakhos ve Melesias’ın Sokrates’ten istediği yardımın ne olduğunu Sokrates nihayet bir soruda toparlar: Çocukların "ruhlarına erdem kazandırmanın en iyi yolu" nedir? (L, 190b, 49) Ancak Sokrates'e göre “erdem”in ne olduğunu bilmeden “onu elde etmenin en iyi yolunu söylememize ihtimal” yoktur. (L, 190c, 49) Örneğin Lysimakhos ailenin adını onurlu bir şekilde sürdürmenin erdem olduğunu düşünüyor. Bu nedenle çocuklarının iyi bir eğitim almasını istiyor. Bu örnekte görüldüğü gibi “erdem”in ne olduğunu şimdiden biliyor olmasak da kendimiz için neyin iyi olduğunu bildiğimizi düşünüyoruz ve öyle anlaş1lıyor ki "erdem”in ne olduğuyla ilgili şimdiden birtakım fikirlerimiz mevcut. Madem ki her insanın "erdem"in ne olduğuyla ilgili bir fikri var, ve erdemin öncelikle "cesaret" olduğunu düşünüyorlar o zaman her bir kimseye göre "cesaret"in ne olduğu sorulup bu cevapların “cesaret”e ilişkin ortak özellikleri tespit edilerek "erdem”in ne olduğu ortaya çıkarılabilir. Ayrı ayrı cesaret örnekleri üzerinden Sokrates'in ulaştığı soru şu olacaktır: “Tüm insanlarda olan cesaret nedir?” (L, 191e, 52) Cesaretin ne olduğunu onun çeşitli örneklerinden hareketle, onun gösterildiği "bütün durumları hesaba katarak" cesaret hakkındaki felsefi ikinci tanımlamayı Lakhes yapar: Cesaret

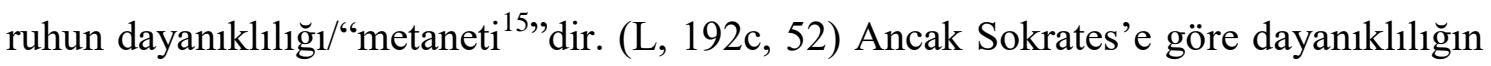
“ “çılgınlıkla [folly] birlikte geleni kötü”"16, metanetin yalnızca "bilgelikle birleşmiş

doğuran gücün kendisi, yani "thumos", Sokrates öncesi düşünürlerden Parmenides’te, doğrudan hakikat/doğruluk arayışının kaynağı şeklinde algılanmıştır (Öztürk 2017: 533-534).

13 "the treatment of the soul". Plato 1952: 29.

14 "for the sake of young men's souls". Plato 1952: 29.

${ }_{16}^{15}$ Gr. karteria, sebat etme, dayanıkl11.k. / "a certain endurance of the soul". Plato 1952: 51.

16 "hurtful and mischievous", Plato 1952: 53. / L, 192d, 53. 
olanı güzel ve iyi"" dir. Böylece "cesaret bilgece metanet olacaktır."18 Atılganlık akıllıca olduğunda ona cesaret diyebiliriz, çünkü, örneğin kahraman dediklerimizden daha güçlü kimselerle karşılaşmamıza rağmen, akılsızca atılganlık gösterdikleri için onlara "cesur" demiyoruz, hatta onlara "anti kahraman" diyoruz. Ruhun "aptalca metanet" ${ }^{\prime 1}$ ine cesaret diyemeyeceğimiz gibi bir bilgiye ya da çıkara dayalı atılganlığın da cesaret olmadığını görüyoruz. Güçsüz olan ve imkanları başarı olanağı için yetersiz görünen ve tüm bunlara rağmen çılgınca görünen bir atılganlık gösteren bir kimse de cesur olabilir. O halde cesaret yalnızca "ruhun bilgece metaneti”yle sınırlandırılamaz. Bilge biri de kaybedeceğini bilmesine rağmen atılgan davranabilir. Bu atılganlık delice görünmesine rağmen bu kimse cesurdur.

Nikias cesaretin nasıl bir bilgi olduğunu detaylandırıyor, buna göre cesaret "savaşta ya da başka bir yerde nelerden kaçıp neleri göze almak gerektiğini gösteren bilgidir.” (L, 195a, 56) Bir kimse nelerden korkması, neleri göze alması gerektiğini ayırt edebilmelidir. $\mathrm{Bu}$ olmaksızın onun atılımı aptalca olacaktır. Böylece, ancak aynı zamanda bilerek cesaret gösteren bir kimse cesur olabilir. Sokrates'e göre cesaretin ne olduğuyla ilgili "bilgi herkeste bulunan bir bilgi değildir". Sokrates bir atasözünü hatırlatır: "Bilgiyle cesaretli olmak her domuzun harcı değildir." (L, 196d, 59) Örneğin bilgelikten pay almadığı ve cesaret bilgisine sahip olmadığı için "Krommyonia domuzu" cesur değildir. İnsan dışındaki canlı türlerin bireyleri birbirleriyle "cesaret bakımından eşit”tirler. (Platon 2011: 196e, 60) Başka bir deyişle onlarda cesaret aranmamalıdır, çünkü cesaret için yeterli olmasa da akıl ve bilgi gereklidir. Nikias şöyle der: "Hayvanlarda cesaret olduğunu kabul etmiyorum, bilmediği için tehlikeyi umursamayan insanda da cesaret yoktur. Böyle insanlara deli ya da cahil cesaretli derim. [...] "Korkusuz ya da cesur olmak birbirinden farklı şeylerdir. Cesaret ve basiret [forethought, ihtiyatl1lık (Plato 1952: 69)] çok az insanda olan şeylerdir; oysa ki cahil

17 Sokrates: "Metanetin bilgelikle birleşmiş olanı güzel ve iyi değil midir?"/ "And endurance joined with wisdom is noble and good?", Plato 1952: 53./ "Oukoun e men meta proneseos karteria kale kagate". Plato, 1952: 52.

${ }^{18}$ Plato 1952: 192 d. 53. "So, by your account, wise endurance will be courage."

19 "foolish endurance". Plato 1952: 193d, 57. 
cesareti [rashness, düşüncesizce atılganlık], ihtiyatsızlıktan kaynaklanan korkusuzluk ya da cüret, [...] herkeste olabilir.” (L, 197b, c, 60)

Ancak, Lakhes bilgi ve cesaretin "birbirlerinden farklı şeyler" olduklarını tekrar hatırlatır. (L, 195a, 57) “Örneğin hastalıklarda nelerden korkulacağını hekimler bilir” diye hekimler cesur insanlar mıdır? (L, 195b, 57) ya da "diğer işçiler de kendi işlerinde nelerden korkulacağını ya da nelere güvenileceğini bilirler. Ama bu, onları cesur yapmaz." (L, 195b, 57) Ayrıca hastalıklardan kurtulmanın ve yaşamı sürdürmenin bilgisi de bir kimseyi cesur yapmaz. Sağlıklı kimsede hasta olma korkusu ya da yaşayan kimsede ölümden korku olabilir. Sağlıklı olmak ya da yaşamını sürdürüyor olmak bir kimseyi cesur k1lmaz. Nikias sorar: Peki "nelerden korkulacağını, nelerden korkulamayacağını" kim bilir? (L, 195d, 58) Bunu kahinlerin bildiğine inanan olsa bile, tek başına bilgeliğin cesaret sağlamadığını daha önce söylemiştik. Onun için kahinlere de cesur diyemeyiz. Kehanetlerin söylediği bir kimsenin nasıl yaşayıp nasıl öleceği hakkındaki bilgi o kimseyi cesur yapmaz. Bilgi ve cesaretin ayrı şeyler olduğu söylenmişti. Cesaret bireylere göre değişiklik gösterir. Bireyi niteleyen bir özelliktir. Cesur kimse tehlikeyi küçümsemez, çünkü düşüncesizce yapılan bir atılganlığa cesaret diyemeyiz, aksine tehlike cesur bir kimse için tehlikedir. Tehlikelidir çünkü dönüştürücü bir güçtür. Cesaret bir kimseyi "kahraman"a ya da "alçak" birine dönüştürür. Cesaret yönündeki bir dönüşüm olumludur, buna bir kimsenin kendisini yüceltmesi diyebiliriz. Bir kahin geçmiş ve gelecekte nelerin meydana geldiğini biliyor diye, ya da mümkün olsaydı, bir zaman yolcusu geçmişe ve geleceğe gidebiliyor diye cesur olmazlar. Nelerden korkulup korkulmayacağını, hangilerine katlanıp katlanmamak gerektiğini kim bilir? Sorusunun cevabına yalnızca söz konusu kimsenin kendisinin tercihi karar verir. Kahinler sonucu söylerler ancak, söz konusu kimsenin bu sonuca nasıl varması gerektiğini söyleyemezler. Hatta, belki en fazla bu kimsenin en az iki seçenek sahibi olduğunu söylerler. Örneğin, Akhilleus öleceğini bile bile, neye katlanacağını kendisi seçerek gitti. $\mathrm{Bu}$ durumda cesareti öğretme konusunda birbirimizden üstün değiliz. Bu nedenle Sokrates Lysimakhos’a şöyle der: "Bence hiçbirimizi seçme.” (L, 201a, 65) Böylece ancak tüm erdemlerle ilgili olarak kendisini 
eğitmek konusunda özellikle düşünsel bir çaba harcayan bir kimse cesur olabilir. Bu anlamda, cesaret arzuyu değil arzunuzu gerçekleştirebilecek şeyleri düşünmeyi gerektirir. Ancak onu düşünürseniz arzunuzu gerçekleştirebilecek şeyi çağırabilirsiniz. Cesaret yalnızca bir kimsenin kendisinin gösterebileceği bir erdem olduğu için, bu konudaki bir açıklamayı belirli bir örnek üzerinden yapmak, cesaretin iyi anlaşılmasını sağlayabilir.

Cesaret bir erdemdir ve tüm erdemler içinde en çok hayranlık duyulanıdır, çünkü Sokrates'e göre cesaret erdemlerin bir parçası olarak kalmaz, dahası tüm erdemlerin kesişim noktasıdır. Yalnızca erdemler açısından bakarak kendini değerlendiren bir kimse ve bu kimsenin yalnızca kendisi, onun cesur olup olmadığı saptamasında bulunabilir. Erdemlerden biri eksik olmasına rağmen gerçekleştirilen atılımın cesurca olmadığını da söyleyemeyiz. Ancak yapılan atılımda bir erdemin eksikliği belirgin bir şekilde göze çarpıyor ise buna cesaret diyemeyiz. Cesaret, örneğin, kendimizin göstermemiz gerektiğini düşündüğümüz, birtakım zamanlarda "ötekinin hizmetine" (Comte-Sponville 2015: 73) sunulduğunda cömertlikle birleşen bir erdemdir. Elbette ego ve haz her zaman eylemlerimize ve düşüncelerimize eşlik eder, ancak cesaret kendi mutluluğunu "ötekine hizmet" etmede bulmayı gerektirir. Bununla birlikte başka bir erdem ise bir kimsenin kendisi ve başkası hakkındaki hassasiyeti, duyarlılığı anlamına gelen düşünceliliktir. Bir kimsenin kendisi ve diğer şey, tür ve kimselerle olan teması, onun cesaret göstermesi bakımından inisiyatif almasını gerektirir. Adı bugüne kalmış cesur kimseler sorumluluk kabul etmiş, görmezden gelmemiş, orada yokmuş numarası yapmamış kimselerdir. İnisiyatif alan kimseler birbirlerinin gözlerinde diğer kimselerin kendi varoluşlarının kanıtını bulabilecekleri üstlenilmiş bir sorumlulukla karşılaşırlar. Kendisinin üstün olduğu düşüncesinden kaynaklanan kibirli bir tutuma cesaret diyemeyiz. Cömertlik gibi başka erdemlerle de ilişkili olduğu görülen cesaret bir erdemdir ve Sokrates'e göre, erdemin ne demek olduğunu bütünlüklü olarak araştırmak “büyük bir iş”tir. (L, 190d, 50) Cesaretin erdemin bir parçası olduğu söylenmişti. Cesaretin bir erdem oluşturabilmesi için “ölçülülük ya da adalet ve kutsallık", cömertlik, aklıbaşındalık gibi başka parçalarının da olması gerekir. Bir kimsede cesaret 
erdemi ancak diğer erdemlerle bütünlüğüne göre bulunabilir. Fakat, cesaret bakımından bütünlüğü oluşturacak erdemler arasında "bilgelik" öncelikli bir yere sahiptir. Cesurca bir davranış bu erdemlerden ne kadar pay alırsa üzerimize düşürdüğümüz güzelliğin pırıltılı 1şı̆̆ı o kadar göz kamaştırıcı olacaktır.

Sokrates cesareti zamanla ilişkilendirir. Ona göre zamansal olduğumuz sürece cesaret bizi düşündürmeye devam edecek. Sokrates: "Bence korkulacak şeyler korku verenler, korkulmayacak şeyler de korku vermeyenlerdir. [...] Sadece geleceğe yönelik korkular korku verir, çünkü korku bir kötülüğün beklenmesidir.” (L, 198b, 61, 62) Sokrates'e göre cesaret gelecekle ilgilidir ve zaman bizden cesaret ister. Cesaret geleceğe doğru yönelir. Böylece, her durumda ya cesuruz ya da korkuyoruz. Sokrates: "Bana göre korkulacak şeyler gelecekteki korkular, korkulmayacak şeyler ise yine gelecekte olup kötülük değil de iyilik sayılabilecek şeylerdir.” ( L, 198c, 62) Sokrates: "Cesaret sadece nelerden korkulup nelerden korkulmayacağının bilgisi değildir. Çünkü o, sadece gelecekteki iyilik ve kötülükleri değil, geçmiştekileri ve şu andakileri, yani diğer bilgilerde olduğu gibi bütün iyilik ve kötülükleri bilir.” (L, 199b, c, 63) Nikias'ın nelerden korkulup korkulmayacağının bilgisi olarak cesaret tanımı, yalnızca geçmişteki şeylerle ilgili olduğu için, bu tanım cesaretin üçte birini veriyordu. Sonuç olarak, cesaretin tanımının şimdi ve gelecekle ilgili olan geri kalan üçte ikisini de buna ekleyen Sokrates'e göre, böylece, cesaret gösterecek bir kimsenin, cesur olmak için yeterli olmasa da "nerede olursa olsun tüm iyilik ve kötülüklerin bilgisi”ni göz önünde tutması gerekecektir. (L, 199c, 63)

\section{Bölüm: Huxley'in Cesur Yeni Dünya Romanının Felsefi Arka Planı}

Huxley'e göre her zaman önemli olan tek bir şey vardır: Mevcudiyetimiz, şimdi ve burada olmamız, tek tek farklarımız ve birlikteliğimiz. Ancak insanların kendi mevcudiyetlerinin farkına varma konusunda ve onların bir arada oldukları yerlerde birlikteliğin insanca yollarını bulmakta başarısız kaldıkları görülüyor. Peki bu önemli 
şeyler nerede ve ne zaman söz konusu edilir? İşte düşünce tarihinde “modernizm” adı verilen şey dikkatimizi bu noktaya çekiyor.

Bizi var olmaktan caydırarak mevcudiyetimizi yok eden temel duygu durumu "korku”dur. Düşünce tarihinde "korku”yu tasfiye çabasıyla belirlenen dönem ise modernizmdir. Caydırma, korku salgını ve buna karşı güvenlik arayışı sadece modern ve modernist dönemin değil bugünün postmodern dünyasının insanlarını da cesaret yoksunluğu ve düşüncesizlikle belirliyor ve bireyleri, onların yaşamlarını simülasyon düzeni içindeki cyborgların mekanik devinimine sahip simülakrlara dönüştürerek modellere indirgiyor.

Modernizmin düşünce tarihinde Nietzsche ile başladığını düşünüyorum. Cesaretlendirici bir düşünür olan Nietzsche tüm düşüncelerini korku salgılayarak yaşamı çölleştiren nihilizme karşı geliştirir. Nietzsche’ye göre nihilizm kendisini, kastrasyon ya da hadım etme ve "insanın "iyi insan" olarak sergilenen hayal edilebilir en kötü sakatlanışı" (Nietzsche 1968: 91, prg. 141) diye tanımladığı "moral kastrasyonizm" olarak gösterir. (Nietzsche 1968: 121) Nihilizmin bu "kastrasyonist ideal”i (Nietzsche 1968: 122) en sonunda “yaşamın kastrasyonu”na (Nietzsche 1968: 143) varır ve insanı yaşamdan koparır. Nihilizm bu özellikleriyle yaşam üzerinde işkencenin bir türü olan, özellikle denek hayvanları üzerinde uygulanan "özdirikesim” (vivisection) (Nietzsche 1968: 37) ile kendisini dayatır. Bedenin kısmi felce uğraması durumu olan hemiplegiayı "erdem”lere ilişkin olarak da yaşıyoruz, Nietzsche buna “erdem hemiplegia”sı adını veriyor. (Nietzsche 1968: 191, prg. 351) Ahlakçılık yaparak nihilizm salgılayan moralistlere karşı Nietzsche şöyle der: "Benim amacım bağlarından koparılmış ve doğasızlaştırılmış moral değerleri kendi doğalarına, başka bir deyişle, kendi doğal “immoralite”lerine tercüme etmektir.” (Nietzsche 1968: 168, prg. 299)

Modernist dönemde nihilizmi İngiltere'de viktoryen değerler temsil eder ve Huxley'in Cesur Yeni Dünya romanı buna karşı bir isyandır. Huxley, viktoryen değerleri, Shakespeare'in Fırtına oyununda "Alışıldık olanın tersini yapardım." diyen Gonzalo gibi iptal eder. (Shakespeare 2015: 38) Modernizmi oluşturan bileşenlere, başka bir deyişle, derinlik modellerine bakıldığında, onları, ortak özelliklerini dikkate 
alarak Yaşam Felsefesi adı altında toparlayabiliriz. Buna benzer bir kavramı Huxley Cesur Yeni Dünya romanının yayımlanışından 14 yıl sonra 1946’da yazdığı “Önsöz”de öne sürer: "Yaşam bilimleri." ${ }^{20}$ Huxley’e göre "yaşamın niteliği”" madde bilimleri, [the sciences of matter $]^{21}$ tarafından değil sadece biyoloji, fizyoloji ve psikoloji, vb. "yaşam bilimleri sayesinde köklü bir biçimde değiştirilebilir.",22

\section{Bölüm: Huxley’in Cesur Yeni Dünya Romanı ve Cesaret}

Cesaret konusu buraya kadar gerçeklerle anlatıldı, şimdi bir kez daha, ancak bu defa hikayeyle anlatılacaktır: Cesur Yeni Dünya romanı. Cesur Yeni Dünya'nın uygar insanları arasında birey ve onun başına gelenler önemli olmadığı için tarihin başlangıç yılını belirlerken de Ford'un bireysel doğum ve ölümünün değil onun topluma sunduğu yararın dikkate alınmış olması gerekir. Buna göre Cesur Yeni Dünya'nın uygar insanları için milad, yeni bir tarihin ilanı olan Henry Ford tarafindan Michigan'daki Highland Park'ta 1 Aralık 1913'te montaj bandının ya da montaj üretim hattının tanıtılmasıyla başlatılır. Romanda geçen olayların yaşandığı yıl Ford'dan Sonra 632'dir, başka bir deyişle, İ.S. 2545'tir. Dünya gezegeninde tek bir dünya devleti kurulmuştur ve bu devlet birbirinden sınırla ayrılmış iki farklı toplumdan oluşmaktadır. Uygar insanların yaşadığı, adı Diğer Taraf olan kısım ve uygar olmayan insanların yaşadığı Vahşi Ayrıbölgeler. İki farklı kısımda yaşayan insanlar için, birbirlerinin tarafına geçmek özel izinlerle mümkündür. Diğer Taraf’’n uygar toplumunun bireyleri yanılmaz bir öjenik ${ }^{23}$ sistemin standart ürünüdür. Öjenik sistem öyle ilerlemiştir ki insan anne rahminde değil yapay ortamlarda, laboratuvar şişelerinde üretilir. Bu işlemin adına Bokanovskileştirme denir. Bokanovskileştirme öjenik sistemi yoluyla insan soyu hiyerarşik bir düzen oluşturacak şekilde beş modele indirgenmiştir: Alfalar, Betalar, Gamalar, Deltalar ve

${ }^{20}$ s. 22. "Önsöz" (1946) Aldous Huxley. CYD, 19-28.

21 "It is only by means of the sciences of life that the quality of life can be radically changed". "Foreword to Brave New World", Aldous Huxley. Çevrimiçi adresi: http://www.wealthandwant.com/auth/Huxley.html, çevrimiçi olduğu tarih: 24 Kasım 2017.

22 s. 22. "Önsöz" (1946) Aldous Huxley. CYD, 19-28.

23 Öjenik: Türün sağlıksız ve kusurlu üyelerini ayıklayarak mükemmel, saf kan ırk oluşturma çalışmasıdır. 
Epsilonlar. Yurttaşlar şartlandırma tekniğiyle sisteme uyacak bir şekilde yetiştirilir. Şartlandırma tekniği yoluyla zihindeki bir imaj, sistemin uygun gördüğü anlamı uyandıracak bir düşünceyle birleştirilir. Şartlandırma çok güçlü bir öğretim tekniğiydi, çünkü “İnsanın birleştirdiğini ayırmaya doğanın gücü yetmezdi.” (CYD, 47) Neyin gerçek olduğu hakkında bir düşüncenin yaratılması şartlandırmanın ne kadar sık aralıklarla yapılıyor olmasına bağlıdır. Gerçek demek tekrar edilmiş olan demekti. Mutluluk ve erdem tek bir ilkede bir araya getirilmişti: "Yapmak zorunda olduğun şeyi sevmek. Tüm şartlandırmaların amacı budur: İnsanlara, kaçınılmaz toplumsal yazgılarını sevdirmek.” (CYD, 42) İnsanın bilinçdışı doğasının istilası anlamına gelen hipnopedya (uykuda öğrenme) tekniği yoluyla insanlar doğru olduğunu düşündükleri bir öğretiyi nasıl öğrenmiş oldularının farkına bile varmadan şartlandırılarak benimsemiş oluyorlardı. Hipnopedya yöntemiyle öğretiler zihne öyle derin işler ki "sonunda çocuğun zihni bu öğretilere dönüş”ür ve “bu öğretilerin toplamı çocuğun zihnini oluştur"ur. (CYD, 53) Diğer Taraf'taki yurttaşların memnuniyetleri, şartlandırma tekniği yoluyla onların zihinlerine yerleştirildiği için, herkes durumundan memnundur. $\mathrm{Bu}$ sanal memnuniyet durumu onları kendileriyle ve başkalarıyla iletişimden koparmıştır. Uygar insanların arasında iletişim yoktur, çünkü insanların birbirleriyle konuşmaları onların şartlandırılmış oldukları sözlerden oluşur. Bu insanlar düşünceler yerine "hipnopedik önyargılar"a sahiptirler. (CYD, 111) Onlar, içinde yaşadıkları sistemle uyum içinde oldukları için bilge olduklarına inanırlar. Ancak, onların bilgeliği "hipnopedik", başka bir deyişle, "uykuda öğrenilmiş bilgelik”tir. (CYD, 189) Bu nedenle felsefeye ihtiyaçları yoktur.

Uygar toplumda bilim kendi gelişiminde özgür değildir. Bilimin gelişmesi ideolojik olarak biçimlendirilir. Eğer bizzat kendimiz ilgilenmiyorsak, her zaman olduğu gibi, bilimin bize ulaşan kısmı otorite tarafından izin verilmiş olduğu kadarıdır. Uygarlığı ya da ütopyayı temsil eden Diğer Taraf'ın 10 denetçisinden biri, Batı Avrupa Bölgesi Denetçisi Mustafa Mond'un şu sözleri bunu daha ayrıntılı olarak açıklar: "Salt bilim konusunda yapılan her buluş, yıkıcılık potansiyeli taşır; bazen her bilim dalına 
olası bir düşman muamelesi yapmak gerekir. Evet, bilime bile. [...] Mutlulukla uyuşmayan tek şey sanat değil, bilim de uyuşmuyor.” (CYD, 224)

Mustafa Mond "gerçek ve güzellik" değil "rahatlık ve mutluluk" (CYD, 227) idealleri üzerine kurulmuş uygar insanların yaşadığı Diğer Taraf'ı şöyle tanımlar: “Dünya şu anda istikrara kavuşmuş durumda. İnsanlar mutlu; istediklerini alıyorlar ve ulaşamayacakları şeyleri de asla istemiyorlar. Refahları yerinde; emniyetteler; hiç hastalanmıyorlar; ölümden korkmuyorlar; ihtiras ve ihtiyarlıktan habersiz ve bundan da çok memnunlar; veba gibi bir illet olan anne ve babaları yok; güçlü duygular hissedecekleri eşleri, çocukları ve sevgilileri yok; şartlandırmaları uyarınca davranmaları gerektiği gibi davranmak zorundalar.” (CYD, 219, 220) Bunlara rağmen bir sorunla karşılaşan bir insan, ağızdan ya da damardan alınabilen, sağlığa zararsız mükemmel uyuşturucu olan soma ile istediği zaman "gerçeklikten uzaklaşıp tatile" çıkabilir. (CYD, 74) Bu kişinin soma tatilinden dönüşü de muhteşemdir, ne baş ağrısı ne de anlatacak saçma sapan mitolojileri vardır. Soma kullanan bir kimse gerçek evrenle kendi zihni arasına "aşılmaz bir duvar” çekmiş olur. Şişelenmiş haldeki embriyonun güvenli durumuna geri döner. Soma alan Kuluçka ve Şartlandırma Merkezi (KŞM) müdürü Henry Foster ve Embriyo Deposu hemşiresi Lenina Crowne'un birlikte yürürlerkenki durumları şöyledir: "Şişelenmiş bir halde caddeyi geçip şişelenmiş halde asansöre bindiler.” (CYD, 95) Diğer Taraf'ın insanları kendilerini şu sözlerle ifade ederler: "Bir şişede geçiririz yaşamımızı." (CYD, 222) ve “acı, bir aldanmadır." (CYD, 247) Soma sayesinde "gözyaşlarından arındırılmış" bir yaşam sürerler. (CYD, 236) Doğal dürtüleri “özgürce tatmin edilir." (CYD, 235) Ancak bu insanlar "mutsuz olma hakkı"ndan (CYD, 238) yoksun bir şekilde "mutludurlar." Mustafa Mond bu topluma “optimum toplum" der. (CYD, 223) "Denge" nihayet kurulmuştur, "uygarlığın kahramanlık ya da yüceliğe hiç ihtiyacı yoktur." (CYD, 235) Duygusal aşırılıklar, örneğin, yan etkileri arındırılmış adrenin ${ }^{24}$ ilacı yoluyla Yapay Şiddetli İhtiras (CYD, 237) oluşturularak dengede tutulur. $\mathrm{Bu}$ uygar toplumun insanları her durumda uyuşturulmuş olmayı tercih ediyor. Onların iş dışındaki boş zamanları artırıldığında,

\footnotetext{
${ }^{24}$ Kortizol ve adrenalin gibi yıkıcı stres hormonlarının uzun süreli etkilerini azaltmak için kullanılan ilaç.
} 
kendilerini tekrar uyuşturma yolları arayarak bu "boş zamandan kurtulmaya" çalışıyorlar. (CYD, 223)

Belki en başta belirtilmeliydi, Diğer Taraf' in yurttaşlarında “zaman" bilinci yoktur. Diğer Taraf’ın yurttaşlarının ne zaman ne yapmaları gerektiğiyle ilgili belirli sabit çizelgeler olduğundan onlar için zaman demek bu belirli etkinlikler demekti. Zaman demek yapılacakları yapmak demekti. Ancak, Psikoloji Bürosu'ndan, hipnopedya uzmanı Alfa-artı modelinden psikolog Bernard Marx bu etkinlikleri bir “zaman kaybı” olarak görüyordu. Lenina buna çok şaşırarak şöyle der: “Öyleyse zaman ne işe yarar ki?” (CYD, 104) Diğer Taraf”ta “zaman”ın olmadığı gibi “doğa” da yoktur. Sınırlı sayıda modellere indirgenmiş insansoyu dışında başka herhangi bir hayvan türünden söz edilmez. Çıplak doğayla karşılaşan uygar bir kimse dehşet duyar. Lenina şöyle der: "Bir tepenin dibinde dikilirken insan kendisini ufackk hissediyor." (CYD, 121) $\mathrm{Bu}$ "yapay zeka"lı (CYD, 116) uygar insanların, doğal güzelliklerden de duyumsanabilecek olan bir estetik deneyim olan "izleme” eylemini gerçekleştirmeleri, sürekli olarak maruz kaldıkları gürültü içinde mümkün değildir. Bernard Lenina’yla birlikte gökyüzündeyken hava aracını durdurur ve şöyle der: "Denizi huzur içinde izlemek istiyorum. O barbarca gürültü sürerken izlemek ne mümkün.” (CYD, 106) Üstelik böyle bir anda bir insan sevdiği kimseyle daha çok baş başa olabilir. Ancak Lenina kendisi için alışıldık olmayan bu ortamdan hoşlanmaz ve korku duyar.

Düzenin korunması için sistemin çarklarındaki hiçbir aksamaya göz yumulmaz, “davranış bozukluğu” (CYD, 155) göstererek düzenle uyumsuzluk içinde olanlara sert davranılır. Bunu Dölleme Odası Müdürü, KŞM Müdürü Henry Ford'a şöyle anlatır: Modellerin birbirine göre "entelektüel üstünlüğü, ahlaki sorumlulukları da beraberinde getiriyor. İnsan ne kadar yetenekli olursa, insanları yoldan çıkarma gücü de o kadar büyük oluyor. Bir çok insan yoldan çıkacağına, bir tek insan acı çeksin, daha iyi. [...] hiçbir suç, davranış bozukluğu kadar bağışlanamaz değildir. Cinayet sadece bireyi öldürür [...] Kolayca yeni bir birey üretebiliriz." (CYD, 156) "Düzenden memnun olmayan, kendi bağımsız düşünceleri olan insanlar. Kısacası, biri olmayı başaran herkes" (CYD, 225-226) düzenin koruyucu yetkilileri tarafından cezalandırılır. Cesur 
Yeni Dünya'nın uygarlığında genel olarak bireyin tasfiye edilmesi ve onun bir biçimi olan ölüm cezasının yokmuş gibi görünmesinin nedeni, sistemin üzerine kurulu olduğu düzenin "tatsız olan her şeyin kökünü kazım”ış olmasıdır. (CYD, 236) Cezalar caydırma, uyuşturma, görevden alma ve sürgün şeklindedir.

Uygarlığı temsil eden Diğer Taraf'ın iktidarı Ayrıbölge insanlarını tasfiye etme, yok etme imkanına sahip olmalarına rağmen "öldürerek tasfiye etme" tutumundan kaçınırlar. Dahası, Ayrıbölge vahşilerinin varlıklarını sürdürmelerine ve istedikleri şeyleri yapmalarına izin verilir. Sistemden ölümü tasfiye etmek yerine, şartlandırma yoluyla yurttaşların ölümle kesintisiz bir haz ve konfor içinde karşılaşmaları sağlanır. Ölümün bir kimsenin hayatıyla ilişkisi uyuşturucu ve şartlandırmalar yoluyla koparılmıştır. Bireyin ölümlü doğasıyla uğraşmak yerine, toplumu sayısal olarak sabitleme yoluyla insan soyunun yaşamının devamının güvence altına alınmasına çalışılır. Böylece uygar toplumda bir insanın uzaklaşması ya da ölümü bir kayıp olarak görülmez. Bununla ilgili hipnopedik slogan şudur: "Kendisini oluşturan hücreler değişse de toplumsal gövde yaşamayı sürdürür.” (CYD, 111) Birini kaybeden birey üzülmemeli, ait olduğu topluma geri dönmeli. Diğer Taraf'ın insanları aklınıza gelebilecek her konuda, ölüm hakkında bile şartlandırılırlar. Her bebek, haftanın iki sabahı Ölecek Hastalar Hastanesi'nde “ölüme şartlandırma”yla eğitilir. "En iyi oyuncaklar oradadır ve ölüm günlerinde kendilerine çikolatalı puding verilir. Ölümü olağan bir olgu gibi kabullenmeyi öğrenirler." (CYD, 169) Bernard şöyle der: "Uygar olmak steril olmak demektir." Uygar insanlar da yaşlanırlar ancak onlar steril halde tutularak hastalıklardan korunduğu ve iç salgıları yapay olarak dengelendiği için genç görünürler ve öldüklerinde fizikleri yıpranmış görünmez. Cesetler Krematoryum binalarında fosfor elde etmek amacıyla yakılıyor, böylece "toplumsal fayda" (CYD, 91) sağlanmış oluyor. Tüm bu nedenlerle ölüm bir kayıp olarak düşünülmüyor.

KŞM Müdürü Henry Foster için insan kaybıyla ilgili hipnopedik öğretinin "Kendisini oluşturan hücreler değişse de toplumsal gövde yaşamayı sürdürür." (CYD, 111) sözü, Ayrıkbölge'de kaybettiği sevgilisi Linda’yı düşündüğünde teselli edici değildir. Üzerinden yirmi y1l geçmesine rağmen, Henry’nin Linda’ya olan sevgisini 
hiçbir şartlandırma söndürememiştir. Henry şöyle der: "Bazen rüyamda görüyorum. Fırtınanın gürültüsüyle uyanıp onun gitmiş olduğunu anlıyorum; ağaçların altında sürekli onu arıyorum.” (CYD, 112) Shakespeare'in Fırtına oyunundaki Alonso'nunki gibi Henry’nin de dileği şudur: "Keşke düşüncelerim de kapansa gözlerim kapanınca." (Shakespeare 2015: 41) Ne var ki gözlerin kapanması düşüncelerin kapanması demek değildir. Henry Foster böylece kendisini, reddettiğgi "dipsiz geçmiş’e" mahkum etmiştir. Hipnopedik şartlandırma tekniği, tüm bunlara rağmen, bilinçdışı psişik alanı tümüyle istila edememiştir. Linda'ya olan sevgisini, dostluğunu artık yalnızca düşlerinde tazeleyebiliyordu.

Uygar dünya insanı için sanat yalnızca eğlence demektir, onun güzel sanatlara ihtiyacı yoktur. Sanat yapıtı yalnızca duyusal filmler ${ }^{25}$ ve kokulu orga indirgenmiştir. Sanat yapıtı uygar insanların kafalarını dağıtmaları ve sisteme daha iyi adapte olmaları için deneyimlenir. Örneğin nosaljik ya da duygusal filmler gösterimden kaldırılmıştır, yalnızca stereoskopik ${ }^{26}$ “duyusal filmler” gösterilir. Böylece gerçeklikten kopulmadı̆̆ gibi gerçeklik "görsel, işitsel ve dokunsal" bir temasla hipergerçek şekilde deneyimlenir. "Gerçeğinden daha gerçek görünüyorlardı; eğer et ve kemikten olsalard1, bu kadar somut bir biçimde göz kamaştırıcı olamazlardı.” (CYD, 173) İnsanların kendi bireyselliklerini hissetmeleri sistemi tehdit edeceği için "tek başına eğlence"ye izin verilmez. (CYD, 169) Lenina'nın hatırlattı̆ğ gibi "Birey hissederse, topluluk sendeler." (CYD, 109)

Ayrıbölge'de insanlar acı çekerler, yaşlanırlar, çirkinleşirler. Lenina Ayrıbölge'de vahşi John'un annesi olan Linda’yı ilk gördüğünde onu iğrenç bulur. Onun bir tür “yaratık” (CYD, 130) olduğunu düşünür. Ayrıbölge'de soma gibi sağlığa zarar vermeyen uyuşturucu yoktur, orada "meskal" ve "peyotl" adlarında "hasta eden" (CYD, 136) uyuşturucular vardır. Ayrıbölge'deki insanlar ya da "vahşiler" tutumludurlar. Elbiseleri eskiyince “yama” (CYD, 132) yaparlar. Oysa Diğer Taraf'taki uygar

\footnotetext{
${ }^{25}$ Duyusal film: (İng. The feely/the feelies) Duyu organlarıyla çoklu bir şekilde hissedilerek izlenen film. The cinema of sesation, multi-sensory cinema.

${ }^{26}$ Stereoskopik: Üç boyutlu deneyimlenen derinlik algısı (stereopsis) yoluyla imgenin yaratılmış ya da artırılmış derinlik yanılsaması.
} 
insanların hipnopedik sloganı: "Yama artarsa refah düşer." "Onarmak, antisosyaldir." (CYD, 132) Ayrıbölge'nin insanları belirsizlikler ve yoksulluk nedeniyle "güçlü hisler"e zorlanırlar, böylece zaman zaman "bireysel bir yalnızlık içinde” yaşarlar. (CYD, 65)

Bir gün John, üzerinde "William Shakespeare'in Tüm Eserleri” (s. 141) yazan “daha önce hiç görmediği bir kitap buldu” (s. 140) ve onu okudu. Gece John uyurken o kitapta okuduğu "garip sözcükler" onun zihninde bir firtına oluşturmuş, "gök gürültüsü misali gümbürdüyordu.” (CYD, 141) Bu kitap onun toplumunun dinine ait kutsal olduğu söylenen sözcüklerden "daha anlamlıydı, çünkü onunla konuşuyordu." (CYD, 141) $\mathrm{Bu}$ sözcükler onun düşündüğü şeyleri "gerçeğe yaklaştırıyor", hatta onun çevresinde olan şeyleri olduklarından "daha gerçek kılıyordu.” (CYD, 142) John, Shakespeare'in kitabından uzun süredir deneyimlediği ancak nasıl ifade edeceğini bilemediği nefretini sözlere dökmesini öğreniyordu. Uygar insanlar şiir okumazlardı. John okumakla kalmayıp, üstelik, bir kez de kendi kulaklarıyla duymak için şiiri yüksek sesle okuyordu. Örneğin, Shakespeare'in Romeo ve Juliet tragedyasından Romeo'nun bir sevgilinin ne demek olduğunu betimleyen sözlerini okur: "Ah! O sevgili ki meşalelere 1şıldayarak yanmayı öğretir./ Asılı durur yanağına gecenin.” (CYD, 182)

Diğer Taraf insanlarının bedensel durumları, arzuları ve sürdürdükleri yaşam tarzı arasında bir çelişki olmadığı için "ruh" problemi de ortaya çıkmıyor. Cesur Yeni Dünya'nın uygar insanlarının sloganlarından biri "herkes herkese aittir." (CYD, 66) Artık bağlılık değil sadakatsizlik geçerli değerdir. Aşk ise bir hastalık olarak görülür. Henry Foster, karşılıksız aşk duygusu yaşayan Lenina'ya baktığında, biraz endişeyle, şöyle der: "Hasta değilsin, değil mi?” (CYD, 189) İnsan şişelenmiş ve şişenin içine ne konulduğu şimdiden biliniyor olduğu için, orada duygu bakımından bir dengesizlik daha baştan dolum sırasında filtrelenmiştir. O nedenle Lenina'nın da ona ilgisi olmasına rağmen John, Lenina'nın mekanik ve sadece gerekliliklerle düzenlenen duygu ve cinsellik konusundaki yaklaşımına alışamazdı. Aşkın bir gereklilik değil özgürce yaşanabilecek bir duygu olduğunu düşünen John: "Hayır, elbette gerekmez. Ama bazı kaba işler asilce yapılabilir. Bir şeylere asilce katlanmak isterdim.” der. (CYD, 193) 
Uygar dünyanın şartlandırmalarıyla yaşayan Lenina için John'un arzuları ve düşünceleri ulaşılmazdı. John, duyusal film sinemasından birlikte çıktıktan sonra, Lenina’yı evine bırakıyordu. John'un ona yeni bir teklifte bulunmaması Lenina’yı baştan çıkarıyordu. Lenina araçtan indi, “topuklarının üzerinde döndü. Vahşi, gözlerini dikmiş sabit bir şekilde bakarak taksinin kapısında dikiliyordu. [...] bekliyordu - ama neyi bekliyordu? Ya da belki de tereddüt edip neye karar vereceğini bilemiyor, sürekli düşünüyordu kim bilir ne muhteşem şeyler düşünüyordu, Lenina hayal bile edemiyordu." (CYD, 175) Vahşi John aslında Lenina'dan hoşlanmaktaydı ancak uygar dünyada aşk bir tür uyuşturucu madde olarak görüldüğü için, bu mekanik sevgi anlayışıyla Lenina John’un onu seviyor olduğunu fark edemez, arkadaşı Fanny Crowne’a şöyle der: "Bazen [John'un benden] hoşlandığını düşünüyorum, bazen de hoşlanmadığını. [...] bana dokunmuyor; bakmiyor bile. Ama bazen aniden dönünce [onu] bana bakarken yakalıyorum.” (CYD, 171) Diğer Taraf'ın insanlarını gözlemlerken deneyimlediği şeyi John şöyle betimliyordu: "Her tarafta kaynayan ayırt edilemez aynılık kabusu". (CYD, 209) İnsanın yaptığı ve insanı bu hale getiren bir dünya karşısında Shakespeare'in Fırtına tragedyasında Miranda "Hey cesur yeni dünya!" der. "Miranda, [...] kabusu bile güzel ve yüce bir şeye dönüştürebilme olasıllğını bildiriyordu. "Hey cesur yeni dünya!" Bir meydan okumaydı bu." (CYD, 210)

Lenina'nın betimlemesiyle Bernard Marx hiçbir şartlandırmaya uymadığı için "gerçekten tuhaf” biridir. (CYD, 103) Bernard kendisini "toplumsal gövdenin bir hücresi” olarak kabul etmez. (CYD, 106) Bernard'ın konuşmaları hipnopedik önyargılardan oluşmaz, aksine o "kendini ifade edecek sözcükler arayan" bir kimsedir. (CYD, 106) KŞM Müdürü Henry, Bernard'ın şartlandırmalara bir “gergedan” (CYD, 104) gibi duyarsız olduğunu düşünüyordu. Bernard'da "ayrı olma hissi” vardı. (CYD, 86) Zaman zaman kendi “ayrıklı̆̆g”nı (CYD, 102) hatırlayıp suçlu hissediyordu. Birey olduğunun farkındaydı. "Tüm hayatı boyunca ayrı olmanın bilincinde olmaktan acı çekmişti." (CYD, 86) Dayanışma Grupları "tek vücut olmaya, bir araya gelmeye, kaynaşıp" kendi kimliklerini "daha yüce bir varlıkta yitirmeye hazır" (CYD, 97) kimselerden oluşuyordu. Ancak Bernard, Dayanışma Grupları'nda başkaları ona 
sarıldığı zaman da "yalnızdı; çok daha yalnız, aslında, hayatında daha önce hiç olmadığı kadar çaresizce kendisiydi.” (CYD, 102) Bernard "tutku nedir öğrenmek istiyorum” diyordu. (CYD, 109) Uygar dünyanın insanları arasında aşk yoktur “dostluk” gibi derin bağa dayalı birliktelik de bulunmaz. Bernard kendisi ile vahşi John arasında gelişen dostluk atmosferinin içinde John'un durumunu betimleyen uygun bir sözcük yaratmıştı: "Kurban-dost" (victim-friend). Bernard bu dostluğu şöyle tanımlıyordu: "Bir dostun temel işlevlerinden biri, vermek istediğimiz, ama düşmanlarımıza uygulayamadığımız cezaları (daha yumuşak ve sembolik bir biçimde) çekmektir." (CYD, 183)

Duygu teknisyeni Helmholtz Watson da "otorite'yle çatışma içindeydi." (CYD, 184) Helmholtz, Bernard'a sorar: "Hiç, içinde dışarı çıkmak için bir şans verilmesini bekleyen bir şey varmış gibi hissettin mi kendini?" (CYD, 87) "Yazılacak başka bir şeyler"in var olduğunun ve bunun için “yazmanın farklı bir biçimi”nin (CYD, 87) var olabileceğini düşünen Helmholtz şöyle diyor: "Eğer doğru kullanırsan, sözcükler X 1şınlarına dönüşebilirler, her şeyi delip geçerler. Okursun ve delinirsin. Öğrencilerime öğretmeye çalıştığım şeylerden biri de bu: Delici biçimde yazmak.” (CYD, 88) Bir defasında, öğrencilere Yüksek Duygu Mühendisliği dersini yapmaktayken, Helmholtz bu sefer "birçok teknik örnek" vermektense müfredattan sapar, bir değişiklik yaparak “yeni yazmış olduğu kendi şiiri” ni okuttu. (CYD, 184) Helmholtz'un amacı bu şiiri yazarken hissettiği şeyleri öğrencilerine hissettirmekti. $\mathrm{Bu} \quad \operatorname{şiir}^{27}$ "yalnızlık hakkındaydı." Şiiri öğrencilere okudu, öğrenciler onu müdüre şikayet etti, müdür de onu kovmakla tehdit etti ve bir süre sonra denetçi Mustafa Mond onu bir adaya sürecekti. Helmholtz'un aklı fikri yapmak istediği şeyde, bu yeni yazı tarzını icat etmekteydi. Bu nedenle madem sürgün edilecekti, hiç olmazsa kötü bir iklimi olan fırtınalı bir adaya

\footnotetext{
${ }^{27}$ Helmholtz'un otoriteyi rahatsız eden isyankar şiiri şöyledir: "Dünkü kurul toplantısı, / Hatırımda, ama patlak bir davul yalnızca,/ Şehirde gece yarısı, / Boşluğa çalan flütler,/ Bıçak açmaz ağızlar, uyuyan suratlar,/ Çalışmayan her bir makine,/ Dilsiz, çöp atılmış mekanlar [the dumb and littered places] ... / İnsanların geçtiği/ Neşelenir tüm sessizlikler [all silences rejoice], / Ağlar (yüksek sesle ya da alçak),/ Konuşur ama ses kimin / Sesi, bilmiyorum./ Susan'ın yokluğu, örneğin,/ Yokluğu Egeria'nın/ Kolları ve göğüslerinin,/ Dudaklarının yokluğu ve ah, evet, kalçalarının,/ Yavaşça vücuda gelir [slowly form a presence];/ Kimin? Ve sorarım, neyin/ Varlığıdır böylesine tuhaf olan [so absurd],/ Öyle bir șey ki aslında olmayan,/ Yine de daha sağlam doldurur geceyi/ Çiftleştiklerimizden,/ Niye sefil [squalidly] gelir ki insanlara bu?" (CYD, 185)
} 
sürgün gitmeyi tercih eder, çünkü ona göre "Ĕger iklim kötü olursa insan daha iyi yazabilir [...] Mesela, bol rüzgarlı ve firtınalı bir yer.” (CYD, 228)

İnsanlar öjenik bir teknikle sentetik şekilde üretilmelerine rağmen yine de onların farklı olmaları mümkündü. Burada dikkat çekici olan şey, insanların birbirlerinden farklı olup olmaması değil ancak hangi toplumda olursa olsun, farklı olanın toplumdan dışlanıyor olması olgusudur. Bunun Cesur Yeni Dünya'da Diğer Taraf toplumundaki kanıtı Bernard Marx ve Helmholtz Watson, Ayrıbölge'deki kanıtı ise John'dur. John bunu şöyle ifade eder: "Eğer farklıysan, yalnızlığa mahkum oluyorsun. [...] beni her şeyden dışladılar. [...] Yine de ben, kendi başıma yaptım.” (CYD, 146) Bernard, Helmholtz ve John geliştirdikleri yaşam tarzlarıyla şartlandırılmış bir mekanik hayattan çıkış yolunu göstermektedirler. Onların yaptığı gibi şeylerin nasıl olup olmadıklarını kendi deneyimimiz yoluyla öğrenebiliriz. Toplumun olumlu onayı umuduyla eyleyen biri kendini caydırıyor ve ancak geçerli bulunduğu sürece kendi kararını açıklıyor demektir. Toplum tarafından kabul edilebilir şeylerin ne olduğu bir bilgidir ve bu bilgiye uygun açıklama ve öneriler yapmak cesaret göstermek anlamına gelmez. Başkasının onayına, onun şimdiden kabul edeceğini bildiğiniz bir şeyi sunmak cesaret göstermek değildir.

\section{Sonuç}

Korkaklığın bir cezası var mıdır? Eğer savaştaysanız bunu hayatınızla ödersiniz. Savaşta değilseniz yine hayatınızla ödersiniz, ancak bu defa hala canlısınızdır. İnsanlar düşüncede, inançta ve genel olarak yaşamlarında, kendilerini, alışkanlıklarla çoğu zaman kendi rızalarıyla korkaklığa mahkum etmeye şartlandırmışlardır. Bir kimse, her sorunun cevabını verdiğini düşündüğü bir kitabı, vicdanının yerini tuttuğuna inandığı bir inanç sözcüsünü ve nasıl yaşayıp nasıl ölünmesi gerektiğini planlamış bir sistemi kabul edip benimsediğinde, artık bu kimseden cesaret konusunda bir sorumluluk bekleyemeyiz. Cesaret hakkındaki ilk felsefi metin olan Platon'un Lakhes'inin içinden çıktığı Grek halkının mitolojisinde "cesaret"in önemli bir yeri vardır. Biliyoruz ki tüm 
destanlar baştan sona cesaret hakkındadır. Zamanın Atina'sında cesaret ve cesareti sergileyen kimse olan "kahraman”ın özel bir yeri vardır. Hatta şöyle bir özdeyiş vardır: Cesaretiyle bilinen “Theseus'suz hiçbir şey yoktur.” Destanlarıyla ve tragedyalarıyla Grek mitolojisi bize cesaret konusunda şunu öğretir: Bir kimse cesaret sergileyene kadar kim olduğunu bilmez. Örneğin "Theseus Atina kralının oğlu olduğunu bilmiyordu”. Gücünü kanıtlayacağı zamana $\operatorname{kadar}^{28}$ ona kim olduğu söylenmeyecekti. Olaylar, cesaret gösterilene kadar yan öykülerden ibarettir. Olayların yapıtlaşması, bir kimsenin cesaret göstermesi ve böylece yan öyküleri kendisine bağlayıp bütünlüğü ya da hikayeyi oluşturmasıyla gerçekleşir.

Cesur insanların kendi yolu vardır. Bu yolda onlara zaman zaman başka kimseler eşlik etse de onlar yalnızdırlar ve onlar başkalarının güvenli diye önerdiği bildik yollardan gitmeyi tercih etmezler. Ona deniz yolunun daha güvenli olduğu söylenmiş olmasına rağmen "Theseus [...] kara yolunu seçmiş ve Atina'ya gelmeden bölgeye korku salan” şeyleri “yere sererek şehre varmıştı.” (Erhat 2002: 285) Bir kimse ya sarhoş ya da zehirlenmiştir. Cesur Yeni Dünya'da Bernard Marx "bireysel varlık ve öneminin bilincine varmaktan dolayı sarhoş, uçuyor" (CYD, 113), “düzen'e kafa tutan" (CYD, 113) biri olarak bu özelliğiyle övünüyordu. Bernard caydırma ya da yıldırma davranışıyla karşılaşmasına ve sürgünle tehdit edilmesine rağmen "zulüm düşüncesi dahi kendisini yıldıramamış, moralini bozacağına güçlendirmişti.” (CYD, 113) Lenina'nın verdiği somalı dondurmayı reddederek şöyle diyordu: “Kendim olmayı yeğlerim. Suratsız da olsa kendim olayım. Ne kadar neşeliyse de başka biri olmak istemem." (CYD, 105) İnsanlara, kendilerini unutturmanın ve onları birbirine benzetmenin en etkili ortamı onları uyutmak, uyuşturmak ve böylece onların kendilerini ve sorunlarını unutmalarını sağlamaktır. Hades'e inen Theseus Persephone'nin sofrasında oturduğu "unutma sandalyesi”nden kalkamaz. (Erhat, 2002: 285) Onu oradan Herakles kurtaracaktır. Şimdilik insan doğasının bir parçası olduğu düşünülen "uyku"

28 Altına saldallarıyla kılıcının saklandığı "bir kayayı kaldıracak duruma gelmedikçe” Theseus'a kim olduğu söylenmeyecekti. Bkz. Erhat 2002: 284-285. 
(Hipnos) ve "ölüm” (Thanatos) ${ }^{29}$ eğer tasfiye edilmiş olsalardı bile yine de insanları kendileri olmaktan ve eylemden alıkoyan başka şeyler her zaman var olacaktı. Cesur kimseleri unutmaktan, kararsızlıktan ve yönsüzlükten koruyan şey kendileriyle ve başkalarıyla aralarında kurdukları bağdır. ${ }^{30}$

Yaşadığımız en dokunaklı anlar insanların birbirlerinden cesaret bekledikleri zamanlardır. Zorluklarla karşılaşan birine “cesur ol!” deriz. Büyük kayıplar yaşamış kimselere "metanet göster!” deriz. Çaresiz bir hastalığa yakalanmış, bakışları ölümün yüzüne saplanmış bir kimseye de “metin ol!" diyoruz. Ancak “cesur ol!" lafını başkalarından duymanın bir anlamı yoktur, çünkü yalnızca kişinin kendisi ne zaman cesur olması gerektiğini bilir. Aynı kişi, ne zaman korkakça davranmış olduğunun utancını da asla unutamaz. Cesaret göstermiş olmamaktan dolayı duyulan utanç en büyük kayıptır. Cesaret sergilemek zaman zaman beden bütünlügünü kısmen ve tamamen yok etse bile bir "kayıp"la sonuçlanmaz. Cesur olmayan bir kimsenin hayatı sendelemelerle doludur, o gerçekten felce uğramıştır. Shakespeare'in Fırtına adlı oyununda korkaklığı ortaya çıkarılıp, ihaneti yüzüne vurulan Stephano şöyle der: "Aman ha dokunmayın bana, ben Stephano değilim, sadece felcim ben." (Shakespeare 2015: 102) Zaman zaman göstermek zorunda hissettiğimiz cesaret erdemini, gerektiği anda göstermediğimizi düşündüğümüzde "utanç duygusu”na mahkum oluruz. Bu nedenle cesaret gösterme sonucu kaybettiklerimizi “yitirilmiş şeyler” olarak değerlendirmeyiz. Vicdanı rahatsız bir kimsenin, onu rahatlatmak için atılımı cesaret olamaz. Cesaret kendine yardım etmek değildir. Cesaret tüm güçsüzlüğünüze rağmen bütün varlığınızı harekete geçirerek yapılan bir atılımdır. Vicdan rahatsızlığı

\footnotetext{
${ }^{29}$ Hesiodos'un Theogonia'sında Erebos (Yeraltı Karanlığı), Nyks (Yeryüzü Karanlı̆̆ı, Gece). Bu iki karanlığın sevişmesiyle 1şıksal varlıklar olan Aither (Esir) ve Hemera (Gün) doğar. Nyks bunun ardından karanlık güçleri üretir. Üç ölüm tanrısı: Moros, Ker, Thanatos. Hypnos (Uyku), Oneiros (Düş); Hesperides (Batılı Gece Kızları); Kader tanrıçaları: Klotho, Lakhesis, Atropos. Öç tanrıçası Nemesis, kavga tanrıçası Eris. Gaflet tanrıçası Ate. Belleği uyuşturan Lethe ırmağı ve en sonunda "belaların en kötüsü olan ant tanrı Horkos.” Erhat 2002: 219. Hesiodos Nyks'in çocukları dediği Hypnos ve Thanatos'u Theogenia'da (758 vd.) şöyle betimler: "Yakaladığı insan kutulmaz hiç elinden/kin besler ölümsüz tanrilara bile.” Aktarılan yer: Erhat 2002: 149.

30 Örneğin Ariadne Theseus'a "Minotauros'un bulunduğu bin bir dehlizli Labyrinthos mağarasında kaybolmaması için eline bir yumak iplik vermişti. Theseus da karışık ve karanlık dehlizlerden ilerledikçe yumağı açıp ipliğ̣i yere bırakıyormuş. Canavarı öldürdükten sonra çıkış yolunu ona bu iplik göstermiş." Erhat 2002: 54.
} 
ertelenebilir, kesintiye uğratılabilir. Cesaret konusunda bir kimse rahatlamasa da olur, ancak bir kimse cesur olmadan yapamaz ya da büyük aksaklıklar yaşar, çünkü utanç duygusu onun yaşamının birlik ve bütünlüğünü bozar. Cesaretle ilişkili olarak "ölüm” bir sorun değildir. Cesur insanlar ölmek zorunda değildir. Eğer bir romanda kahraman erkenden öldürülmüş ise, yazar şimdiden, en az önceki kadar cesaret gösterecek birini yaratmaya başlamış demektir. Cesur insanların hayatına yakından bakacak olursak onların ölüm hakkında bir planlarının olmadığını görürüz. Cesur insanlar, birçoğumuzun yaptığı gibi şimdiden mezarlarının hangi taşlarla ve mobilyalarla süsleneceğini vasiyet etmezler. Onlar bir şekilde yaşamın niteliğini artırmaya odaklanırlar. Albert Camus'nün Sisifos Söyleni kitabının başında dediği gibi “yakılıp ölmeye" (Camus 2014: 21) değmeyecek bir gerçek uğruna kendisini katlettirmedi diye Galilei’ye korkak diyemeyiz. Ancak birtakım zamanlarda da bir kimsenin tutkusunun dayanıklılığı onun bedenini geride bırakabilir ve bu kimse, Cesur Yeni Dünya'daki vahşi John gibi, Shakespeare'in Othello tragedyasında geçen şu sözü sayıklayabilir: "Bir huzur gelecekse her firtınanın ardından, essin rüzgarlar ta ki ölümü uyandırana dek." (CYD, 10)

Lakhes diyaloğunun başında, Lysimakhos ve Melesias, Nikias ve Lakhes'i bu alana davet ederlerken onlara ne için davet edildiklerini söylememişlerdi, çünkü Lysimakhos'a göre "bazı insanlar” cesaret erdemini öğretme iddiasında olan "böylesi antrenmanlarla alay ederler, fikirleri sorulduğu zaman kendi düşündüklerini söylemek istemezler." (178a, s. 35) Böyle olduğu için de bu insanlar çoğu zaman "kendi düşüncelerinin tersine bir şeyler söylerler.” (178a, s. 35) Bu nedenle, bu tür durumlarda neyin söyleniyor olduğundan çok nelerin söylenmediğine dikkat edilmelidir. Şartlandırmanın alternatifi diyalog başka bir deyişle iletişimdir. Gerçekten bir diyalog içine girmek için, tartışma içinde olunan kimselerin düşüncelerini, onların söyle(ye)medikleriyle de dikkate almak gerekir. Ebeveynlerimiz bizi ne kadar başıboş bırakırsa bıraksın ya da öğretmenler bilgi denilen şeyi ne kadar reflekslerin şartlandırılmasına indirgerlerse indirgesinler Sokrates'in dediği gibi hala cesaret gösterip bir otodidakt olma ve kendi yolumuzu çizme olanağımız vardır. Lakhes 
diyaloğunun hemen başında Lysimakhos çoğu kimsenin çocuklarını "başıboş” (L, 179a, 35) bırakmasının, onların iyi yetişmeyecekleri anlamına geldiğini söyler. Lysimakhos'un bu düşüncesi bir Cizvit atasözüyle aynı anlayışı paylaşır: "Bana çocuğun aldığı eğitimi söyle sana yetişkin halinin dini inançlarını söyleyeyim." ${ }^{31} \mathrm{Bu}$ söz bir palavradır, çünkü, belki hocalarının haberi yoktur ama öğrenciler hocalarının ne söylediklerine değil neleri söyle(ye)mediklerine dikkat ettiklerinde başarılı olurlar. $\mathrm{Bu}$ bakımdan "modern pedagog, öğrencilerinin reflekslerini şartlandırma konusunda, Voltaire'i yetiştiren değerli rahipler denli başarılı değildir." 32 Papaz hocalar ne derse desin Voltaire'in gözünde onlar gerçek hakkında asla konuşamazlar, çünkü hocaların yüce gerçek saydıkları Tanrı kendi sessizliğini hep korumuştu. Bu nedenle, bir hocanın yapacağı en iyi şey, Tanrı'nın yaptığı gibi yapmak ve konuşmuş olsa bile gerçek konusunda aslında sessiz kaldığını itiraf etmektir. Kitleler kendilerine "kanaat telkin etme" ${ }^{, 33}$ girişiminde en sonunda şunun farkına varırlar ki kendilerine söylenenlerden çok kendilerine söylenmeyen şeyler gerçekliğin ne olduğunda belirleyicidir.

Grek mitolojisinde Dionysos'un temsil ettiği sarhoşluk ya da intoksikationı, Grek mitolojisindeki Prokrüstes'in ${ }^{34}$ insanları uyuşturma ve damgalama yoluyla çerçeveleyip sisteme uyduran davranışından ayırmamız gerekir. Bugün, uygulamalı bilimlerle uğraşan bilim insanları "modern giysilere bürünmüş Prokrustes'ler"dir. ${ }^{35}$ Onlar “insanlığın üzerinde yatacağı yatağı hazırlayacak ve eğer insanoğlu yatağa uymazsa, bu, insanlık için çok kötü olacak. Birtakım uzatma ve kısaltmalar ${ }^{36}$ olacak, insanlığın fazla gelen uzuvları kesilip biçilecek." ${ }^{37}$ Ancak bugün uygulamalı bilimlere eklenen nükleer çalışmalarla birlikte "aynı türden uzatma-kısaltma ve uzuv kesmeler, ancak bu kez,

\footnotetext{
31 s. 25. "Önsöz" (1946) Aldous Huxley. CYD, 19-28.

32 s. 26. "Önsöz" (1946) Aldous Huxley. CYD, 19-28.

33 "to influence opinion." "Foreword to Brave New World", Aldous Huxley. Çevrimiçi adresi: http://www.wealthandwant.com/auth/Huxley.html, çevrimiçi olduğu tarih: 24 Kasım 2017.

${ }^{34}$ Prokrustes "Atina ile Megara yolu üstünde bulunan bir haydut. Biri küçük, biri büyük iki yatağı varmış ve gelen, geçen yolcuları soyduktan sonra uzun boyluları küçük yatağa yatırır, ayaklarını keser, kısaları büyük yatağa yatırır, ayaklarından çeker, uzatırmış." Theseus onu öldürmüştür. Erhat, 2002: 254.

35 s. 24. "Önsöz" (1946) Aldous Huxley. CYD, 19-28.

36 "some stretching and a bit of amputation".

${ }^{37}$ s. 24. "Önsöz" (1946) Aldous Huxley. CYD, 19-28.
} 
geçmiştekinden çok daha korkunç" ${ }^{38}$ ve kalıcı olacaktır. Hepimizin bildiği gibi kapitalizmin yazgısı ve kendini yenileme firsatı olan ekonomik krizler, iktidarın merkezileşmesi ve artan devlet kontrolü günümüzde totaliterleşmeye doğru eğilimi daha da artırmıştır. Rus filozof Nicolas Berdiaeff ile (1874-1948) aynı görüşü ${ }^{39}$ savunan Aldous Huxley yirminci yüzyıldaki teknolojik gelişmeye bakarak bu şartlar altında bugün ütopyanın gerçekleşmeme kaygısından çok ütopyanın gerçekleşme ve "refah tiranlığına dönüşme" ${ }^{40}$ korkusunun söz konusu olduğunu düşünür. Bu nedenle Huxley Cesur Yeni Dünya'nın bir distopya değil bir ütopya olduğunu söyler. Huxley’e göre, yukarıda sözü edilen, totaliterleşmeyi ve ütopyanın bir refah tiranlığına dönüşme riskini iktidarın “merkezsizleştirilmesi” ve “özyardım yönünde büyük ölçekli kitlesel bir hareket"le ${ }^{41}$ durdurabiliriz. Düşünce ve bilim insanlarının üzerine düşen sorumluluk özellikle "uygulamalı bilimler"i, insanı araçsallaştırmaktan vazgeçmeleri konusunda sürekli olarak uyarmaktır. Düşünce ve bilimin mümkün oldukça "özgür bireylerden oluşan bir insansoyu"42 yaratmanın aracı olarak kullanılması telkin edilmelidir. Eğer herbir insanı toplumun nasıl düzenlenmesi gerektiği konusunda mutlak yetki sahibi yapabilseydik, sonuçta kaç insan var ise o kadar hapishane inşa edilmiş olacağını düşünüyorum. "Sizin görüşlerinize katılmayan ya da planlarınıza uymayan insanlarla ne yapacaksınız?"43 Şimdiden hazır bulduğumuz günlük hayatın düzeni, şartlandırılmış bir şekilde bilincimize yerleştirilmiş olduğu için bunun farkında değiliz. Neyin normal olduğunu şimdiden biliyoruz. Çoğu zaman hazır bulduğumuz günlük hayatımızın düzenini değiştirmek kolay değildir. Bir kimsenin kendisini ve yaşam tarzını değiştirmek cesaret ister. Bunu yapmaktansa mevcut düzene uyum sağlamak çoğu

${ }^{38}$ s. 25. "Önsöz" (1946) Aldous Huxley. CYD, 19-28.

39 Huxley ütopyanın bir refah tiranlığına dönüşme riski konusunda Rus filozof Nicolas Berdiaeff ile (1874-1948) aynı fikirdedir. Huxley bu nedenle Cesur Yeni Dünya romanına Berdiaeff'in sözleriyle başlar: "Ütopyalar şimdi eskiden sanıldığından daha çok gerçekleşebilir görünüyor. Bizse bugün kişiyi bambaşka kaygılara düşüren bir sorun karşısında bulunuyoruz: $\mathrm{Bu}$ ütopyaların kesin olarak gerçekleşmesini nasıl önleyebiliriz? Ütopyalar gerçekleşebilir şeylerdir. Belki de yeni bir çağın başındayız; öyle bir çağ ki, aydınları ve olgun kişileri ütopyaların nasıl önlenmesi gerektiğini ve ütopik olmayan daha az "mükemmel", ama daha çok özgür bir topluma nasıl dönülebileceğini düşünmeye başlayacaklardır." CYD, 29.

${ }^{40}$ s. 28. "Önsöz" (1946) Aldous Huxley. CYD, 19-28.

${ }^{41}$ s. 25. "Önsöz" (1946) Aldous Huxley. CYD, 19-28.

42 s. 28. "Önsöz" (1946) Aldous Huxley. CYD, 19-28.

${ }^{43}$ s. 11. "Sunuş", Margaret Atwood. CYD, 7-17. 
zaman tercih edilir. Mevcut düzen ve hayalimizdeki ideal yaşam ya da ütopyamız arasında her zaman bir uçurum vardır. Bu nedenle kendimizi her zaman bir distopyada bulduğumuzu, dahası geçmişte "ütopya" olarak yazılan tüm yapıtları da "distopya" olarak görebileceğimizi düşünüyorum. Hatta daha ileri gidip kendimize şunu söyleyebiliriz: "Sadece benim ütopyam var." Geçmişte yaşamış ve ölmüşler sayıca daha fazlaydı ve onların çoğu korkaktı. Günümüze sadece cesurların ve korkaklıkta sınırları zorlayanların adları kalmıştır. Cesaretle ilgili okuduğumuz bu düşünceler sonuçta başkalarına aittir. Bunlar bir kimsenin kendi düşünceleri olmaksızın o kimse kendisinden hiç bahsetmiş sayılmaz. Bu nedenle ütopya ve cesaret konusunda bir kimsenin söyleyebileceği en güzel söz: “Bunların hiçbirine katılamam!” demektir.

Bir inanç sözcüsü nihilist moralist Blaise Pascal diyor ki inanç ve dinden yoksun bir insan "bir canavar ve bir kaostur." (Nietzsche 1968: 52, prg. 83) Ancak toplumsal bakımdan, cinsellik ve maddiyata yaklaşım açısından inanç sözcülerinin durumunun hüsrana uğramış olduğunu görüyoruz. Moralistler, insanları ikna edecek hiçbir iyi ve kötü değer kalmadığını bugün daha iyi biliyorlar. Beyaz gelinciklerin hepsi ahlakın çamurlu sularına zorlandı ve hiçbiri karşı tarafa temiz çıkamadı. Kendi içlerinden dünyanın bir an önce sonunun gelmesi için yalvaran inanç sözcüleri de hiçbir Tanrı'nın insanlar arasından sağ çıkamacağını ve İsa bir daha gelse onu tekrar çivileyeceklerini iyi biliyorlar. Bundan dolayı inanç sözcüleri yeni bir kitap ya da yeni tanrılar getirmekten yüzyıllar önce vazgeçtiler. Nihilizmin aktörleri olan moralistlere, inanç sözcülerine ve mevcut uygulamalı bilimlerin aktörlerine prokrüstesyan tutumdan vazgeçmeyi ve yüzlerini yaşama dönmelerini öneriyorum. Yaşamı neyle savunuyorsak onunla sürdürüyoruzdur, çünkü bizim hakikatimiz bizim hikayemizdir. Kanımızı kime içiriyorsak hakikat oradadır ve kanımızı kim içiyorsa hikayemiz orada yazılmaktadır. Ona kendisi hakkındaki hakikati soran Odysseus'a kahin Teiresias şöyle cevap verir: “Amma yaptın, bundan kolay ne var, / Ölmüşlerden kimi yaklaştırırsan kana, / o gerçeği söyler sana olduğu gibi”. (Homeros 2005a: Bölüm XI, 202)

Yüzümüzü yaşama dönmek, kendi hikayemizi oluşturmak devrimci bir eylemdir. Huxley’e göre insanın düşünsel ve bedensel yönünü bir arada dikkate almayan bir 
değişikliğe devrim diyemeyiz. Huxley “devrimci devrim” diye bir sözcük öne sürüyor. Şöyle diyor: "Devrimci devrim, dış dünyada değil, insanların ruhları ve bedenlerinde gerçekleşmelidir."44 Yüzümüzü yaşama dönük tutma konusundaki duyarlılığımızı nasıl koruyup geliştireceğimiz hakkında ilk dikkat etmemiz gereken önemli özellik ruhumuzu ya da psişik varlığımızı oluşturan “düşünme gücü”dür. Düşünme gücünün insanın yaşıyor olmasının kanıtı olduğunu Grek mitolojisinin en cesur adamı olan Akhilleus'un Odysseus’a Hades’te söylediği şu sözlerinde buluyoruz: "Nasıl göze alabildin Hades’e inmeyi,/burada ölüler oturur, düşünme gücünden yoksun olanlar, / işi bitmiş ölümlülerin görüntüleri.” (Homeros 2005a: Bölüm XI, 211) Grekler ölümün, düşünme gücünden yoksunluk demek olduğunu biliyorlard1. Yüzümüzü yaşama dönük tutma konusundaki ikinci önemli özellik, Cesur Yeni Dünya romanının bize hatırlattığı, başka hiçbir zamanla kıyaslanamayacak kadar muazzam bir şey olan şimdide, şu anda mevcut olduğumuz bilincidir. $\mathrm{Bu}$, işin bedensel yönüdür. Bireylerin var olduklarını, mevcut olduklarını onlara hissettiren en etkili alan duyusal etkilenim yeteneğidir. Shakespeare'in Firtına oyununda Prospero'nun dediği gibi: “En s1k1 yeminler bile / Samandır kanın ateşinde." (Shakespeare 2015: 77) Kitleleri bireysel varoluşları konusunda etkilemek ve dönüştürmenin en güçlü alanı, onların duyusal beğenilerinin farkına varmalarını sağlamaktır. Vahşi John'un dediği gibi: "Dudaklarımız ve gözlerimizdeydi sonsuzluk." (CYD, 161) Bugünkü yanılgımız, çeşitli uyuşturucu maddelerle mevcudiyeti terk ederek çıktığımız kısa süreli tatilleri sonsuzluğun parçaları olarak görmektir. Duyusal beğeni konusunun en dokunaklı ve uyarıcı görünümü erotik yetiler alanıdır. $\mathrm{Bu}$ konuda Shakespeare'in anlayışının bile elle tutulur bir tarafı olduğunu düşünmüyorum. Onun duygular hakkında söyledikleri etkileyicidir ancak dünyevi tenin içine saplanmış yaralı bir yüreğe kulaktan şifa verilemez. Bu tür moralist yazarların yapıtları konuyu "iffetlilik/orospuluk söylevleriyle" ${ }^{\text {"45 }}$ karartır. İşte bu nedenle cinsellik ve erotik yetiler alanı ütopyaların üzerinde durduğu temel konulardır. Ne yazık ki erotik yetiler konusunda insanlık hala ne yapacağını bilememektedir.

${ }^{44}$ s. 23. "Önsöz" (1946) Aldous Huxley. CYD, 19-28.

${ }^{45}$ s. 9. "Sunuş", Margaret Atwood. CYD, 7-17. 
Erotik yetilerin farkına vardırılma çabasıyla ilgili olarak, Cesur Yeni Dünya romanında geçen iki çarpıcı örnek vereceğim. Sevişme öncesi hamilelik riskinin ne büyük bir korku olduğunu ve sistemin birçok konuda olduğu gibi bu konuda da kadınları daha fazla ezdiğini herkes bilir. Bu konudaki gözlemleri yapabileceğiniz en dokunaklı yerler kadın doğum ve çocuk hastalıkları hastaneleridir. Bu konularda sorabileceğiniz en tecrübeli insanlar ise buralarda çalışan Margaret Sanger (1879-1966) gibi hemşirelerdir. Huxley'in Cesur Yeni Dünya kitabını yazıyor olduğu sıralarda ABD'de doğum kontrol araçları kullanımı yasaktı. Bu konudaki aktivist Margaret Sanger (1879-1966) polis tarafından baskına uğrayan ilk doğum kontrol kliniğini 1950 yılında açarak doğum kontrol hapını geliştirmek için çalışmalara başladı. Yirmibirinci yüzyılın başında yaşayan kimseler olarak bizler, bu konuda birçok yasal zorluklar olmasına rağmen gerçekten iyi zamanlarda yaşıyorlar. Gebeliği önleyici ilaç veya araç olan kontraseptiflerin geliştirilmesi uzun ve zorlu bir tarihten geçerek günümüzde çok güvenli hale getirilmiştir, hatta doğum kontrol hapı kullanan kadınların diğerlerine göre daha uzun yaşadığı artık bilinen bir farmakolojik bulgudur. Erotik yetilerin farkına vardırılma çabasıyla ilgili ikinci örnek ise giyim hakkındadır. Giyinip soyunmak ne büyük bir derttir. Cesur Yeni Dünya'yı okumuş birinin aklında en azından orada geçen fermuarların “cırt!” sesleri kalmıştır. (CYD, 151) Huxley'in düşünceleri zamanın teknolojisine göre gerçekten ütopiktir. İnsanın duyusal haz alanlarından cinsel yaşamı için büyük bir konfor sunan İsveçli mühendis Gideon Soundback'in 1913 y1lında icat ettiği fermuarlar da yirminci yüzılın doğum kontrol hapları gibi büyük bir buluşudur. Margaret Sanger ve Gideon Soundback gibi kimselere toplumsal bir soruna işaret edip o konuda çeşitli alternatifler önerdikleri ve mümkünse pratik eylemlerle bu sorunların aşılması için mücadele verdikleri için sosyal reformcular denilir.

Sokrates ve Huxley bizi, sınırlı sayıda standart modellerden oluşan kalabalıklar haline indirgeyen sistemi sevişerek ve felsefe yaparak yıkıp değiştirebileceğimizi düşünüyorlar. İnsanların kendilerinden, birbirlerinden ve dünyadan uzaklaştıkları böyle bir çağda felsefe yapmak Lysimakhos’un farkına vardığı ve Sokrates'e söylediği gibi kendinizle ve başkalarıyla aranızdaki “dostluğu yenilemek”tir. (Platon 2011: 38, 181c) 
Kendi bireyselliklerinin farkında olmayan ve diğer kimselerin bireyselliklerini aile, ahlak, din, toplum, kültür, devlet, yasalar vb. şeylere referansla görmezden gelen insanlardan dost olmaz. Dikkatli bakacak olursanız bugün insan bireylerinin bir aileye ait olamayacaklarını biliyoruz artık. Örneğin, yakından bakacak olursanız, bireylerin içine hapsedildikleri ailenin bugün hiçbir anlamı kalmadığını göreceksiniz. İnsanların kedi ve köpeklerle olan birliktelik süreleri eşleriyle ve kan bağı olan kimselerle olan birliktelik sürelerinden daha uzundur. Bugün "aile" denilen şeyin moralist totaliter bir zihniyete sahip otoriteler tarafından, insan üretimi yapılmak üzere desteklenip işletilen küçük çiftlikler olduğunu daha net bir şekilde görmekteyiz.

Zevk ve hazları yok etmek ya da onları sıradanlaştırıp uniformelleştirmek her zaman mevcut olan ve kendimizi içinde bulduğumuz sisteme özgüdür. Buna karşı ne yapabiliriz? Benim önerim şudur: Önyargıları, tabuları ve darkafalılı̆̆ı yıkabiliriz. Zevklerimizi incelterek beğenilerimizi oluşturalım ve deneyimleyelim. Albert Camus'nün Veba adlı romanında dediği gibi, Paris sokaklarının kokusunu nasıl hissedeceğimizi hiçbir kitaptan okuyamayız. Mesele konformist olmak ya da sarhoş olmak değil, asıl mesele uyuşturulmuş ya da zehirlenmiş olmamaktır. Tüketimin hala toplumsallaştırılamadığı bir geçiş döneminde birbirimizi asla konformistlikle suçlamamalıyız ve asla hiçbir şeyi yeterli bulmamalıyız. Kendimize şöyle diyelim: "Bunlar zaten olmalıydı."

Yapmış olduğunuz hatalar için kendinize işkence yapmayın. Pişman olmuşsanız bile, kendinizi aklamak için aynı çamurlu suda debelenerek arınmaya çalışmayın. Böyle durumlarda bir sanat yapıtı olduğunuzu düşünün. Unutmayın bir sanat yapıtı düzeltilemezdir, o bir bütündür ve bu nedenle o biriciktir. Ayrıca yaşamın tadı bir inanç konusu edilemeyecek kadar keskindir. Yaşamın tadını iletme konusunda her türlü inanç yetersiz kaldığı içindir ki inanç sözcüleri onu öte dünya vaadiyle ertelerler. Bunun farkında olan otoriteler yurttaşlara ideal bir yaşam sunamadıkları için onları sayısız uyuşturucularla kısa süreli tatillere çıkarırlar.

Evet, herkes cesur olmak zorundadır, çünkü bireylerin cesur olmamaları onların kötülüğe karşı koyamıyor oldukları anlamına gelir. Yurttaşları cesur yetiştirilmemiş bir 
toplum yozlaşmaya, çürümeye mahkumdur, çünkü korkuya kapılmış bir kimseden kendi sorumluluklarını yerine getirmesi beklenemez. Cesaret, sonuç olarak, tek başınıza sergileyebileceğiniz, tek kişilik bir eylemdir. Böyle olduğu için cesaret güçlü olarak tanınan kimselerin değil daha çok yumuşak, güçsüz ve zayıf olarak tanınan kimselerin beklenmedik, şaşırtıcı davranışıdır. Bu tür kimseler güçsüz olmalarına rağmen doğru olmadığını, yanlış olduğunu bildikleri şeyi kabul etmezler, reddederler ve engellemeye çalışırlar. Onlar yanlış olduğunu düşündükleri bu şeye itiraz ederler, başkaldırırlar ve direnirler. $\mathrm{Bu}$ tür kimselere sistem tarafından caydırılamamış, yıldırılmamış olanlar diyebiliriz. En sonunda Akhilleus da güçsüzdü, bedeninden gelen bir zayıflıktan ölümcül bir yara alarak öldü. Bu nedenle cesarete ilişkin olarak hiç kimse kendisini küçümsememelidir. Cesaret konusunda birbirimizden üstün değiliz.

Günlük hayatınızda iletişim dediğiniz şeye daha yakından bakacak olduğunuzda, kullanıldığı çoğu yerde onun, üsttekilerin alttakileri ve alttakilerin birbirlerini şartlandırılmış bilgelikleriyle caydırmaya çalıştıkları bir araç olarak kullandıklarını göreceksiniz. Cesur Yeni Dünya romanında Bernard Marx KŞM Müdürü Henry Foster tarafından “toplum düşmanı" (CYD, 156) ve "uygarlığa karşı bir komplocu” (CYD 157) ilan edilmesine rağmen kendi düşüncelerinden caydırılıp yıldırılamamıştır. Sistemin caydırma aracıyla korku salgılamasına karşı önerim şudur: Bernard'ın yaptığı gibi kendimizi ifade edecek sözcükleri arayalım ve Helmholtz’un yaptığı gibi kendimizi ifade etmenin tarzlarını geliştirmeye çalışalım. Sonuç olarak, anıtımız kendi etrafımızdadır. Ne kadar cesur olduğumuzu tam ortasında durduğumuz çevremize bakarak anlayabiliriz. Cesur olmayan bir kimse yalnızca efendileri değiştirir. Shakespeare'in Fırtına oyununda irrasyonel güçler tarafından batırılan gemiden kurtulup adaya vuranların hepsi, tahta oturma dürtüsüyle, bu firtınada önce en güçlünün, kralın ölmüş olacağına kendilerini inandırırlar. Fakat, özgürlük için herbir kimsenin efendi olma ya da bir efendi bulma arayışından kaçınması gerekir. Cesaretlendirmek istediğiniz kimsenin kulağına șöyle fısıldayın: "Sen özgürsün." Bernard'ın baştan çıkarıcı sözlerini hatırlayalım: "Özgür olmak istemez miydin, Lenina? [...] başka bir 
şekilde mutlu olmak istemez miydin, Lenina? Başkaları gibi değil, kendi istediğin gibi.” (CYD, 106-107)

Ütopya ve cesaret düşüncesinin kaynağı zaman deneyimimizin birlikli bir biçimidir. Cesur olmak ve başka bir dünya kurmak için sadece kendimizi dinlememiz yetecek, çünkü dilin gramerinde zamanın gelecekte bitmiş zaman kipinin deneyimine ya da düşlere sahip tuhaf bir varolan olduğumuzu hergün binlerce kez söylüyoruz. Yazıyı, Huxley'in Cesur Yeni Dünya kitabının adını içinden koparıp aldığ ${ }^{46}$ Shakespeare'in Fırtına oyunundan Prospero'nun sözüyle tamamlamak istiyorum: "Biz, düşlerin mayasından yaratılmışız / ve uykuyla çevrelenmiştir kısacık hayatımız." (Shakespeare 2015: 82) Umarım bu güzellikleri düşünürken gözgöze gelip dostluğunuzu yenileyebilirsiniz.

\footnotetext{
${ }^{46}$ Miranda: “Ah harika!/Ne hoş yaratıklar doldu burası!/Ne de güzelmiş insanlar!/Böyle insanlarla dolu güzel [cesur] yeni dünyaya merhaba!”. Shakespeare 2015: 97.
} 


\section{KAYNAKÇA}

ARISTOTELES (2008). Retorik, çev. Mehmet H. Doğan, İstanbul: YKY. Yayınları.

CAMUS, Albert (2014). Sisifos Söyleni, çev. Tahsin Yücel. İstanbul: Can

COMTE-SPONVILLE, André (2015). Büyük Erdemler Risalesi, çev. Iş1k Ergüden, İstanbul: İletişim Yayınları.

ERHAT, Azra (2002). Mitoloji Sözlüğ̈̈, İstanbul: Remzi Kitabevi.

HOMEROS (2005). İlyada, çev. Azra Erhat \& A. Kadir, İstanbul: Can Yayınları.

HOMEROS (2005a). Odysseia, çev. Azra Erhat \& A. Kadir, İstanbul: Can Yayınları.

HUXLEY, Aldous (2017). Cesur Yeni Dünya, çev. Ümit Tosun, sunuş: Margaret Atwood, sonsöz: David Bradshaw, İstanbul: İthaki Yayınları. Kitabevi.

KANT, Immanuel (1984). Seçilmiş Yazılar, çev. Nejat Bozkurt, İstanbul: Remzi

NIETZSCHE, Friedrich (1968). The Will to Power, tr. by Walter Kaufmann and R. J. Hollingdale, ed. By Walter Kaufmann, New York: Vintage Books.

ÖZTÜRK, Ümit (2017). “Parmenides Ontolojisi’ Hakkında: Bir Başlangıç”, Mavi Atlas, 5(2)/2017: 530-548.

PLATO (1952). Laches, Protagoras, Meno, Euthydemus, tr. by W.R. M. Lamb, Cambridge: Harvard University Press.

PLATON (2001). Lysis, Lakhes, çev. Sabahattin Eyüboğlu \& N. Şazi Kösemihal. İstanbul: Sosyal Yayınlar.

PLATON (2007). Devlet, çev. H. Demirhan, Ankara: Palme Yayıncılık.

PLATON (2011). Lakhes, çev. Furkan Akderin, İstanbul: Say Yayınları.

SHAKESPEARE, William (2015). Firtına, çev. Özdemir Nutku, İstanbul: Türkiye İş Bankası Kültür Yayınları. 